\title{
Surfactin-Like Biosurfactant Production and Optimization by Bacillus Subtilis SNW3: Product Characterization and Its Influence on Seed Development and Plant Growth
}

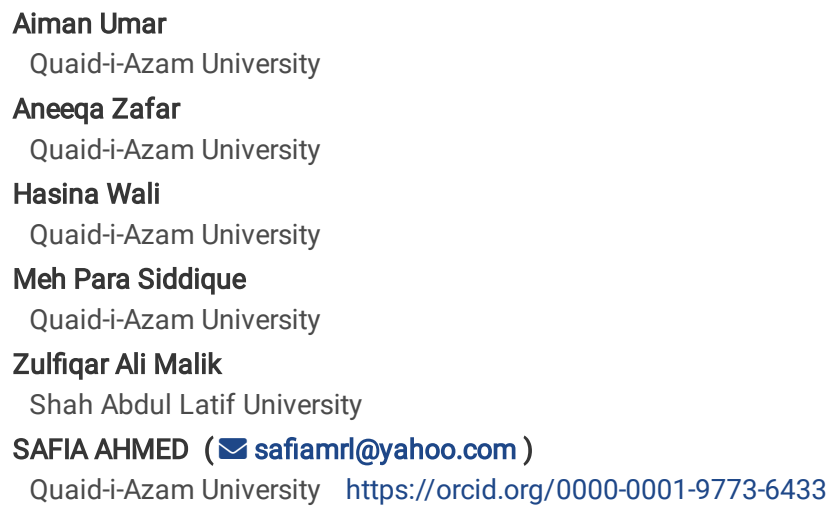




\section{Abstract}

Background: Biosurfactants, being environment friendly, highly biodegradable, less toxic and stable compounds have applications in several environmental and industrial sectors that includes cosmetics, biomedical, bioremediation, and agriculture. Growing concern about eco-friendly compounds leads to replacement of chemical surfactants with biological surfactants. However, use of biosurfactant limits due to high production cost. Surfactin, a class of lipopeptide, considered as powerful biosurfactants having wide applications in therapeutics and environmental field. This study aims to investigate production and characterization of surfactin by Bacillus subtilis SNW3 and evaluating their potential application in seed germination and plant growth.

Results: In present study, Bacillus subtilis SNW3 was previously isolated from Chakwal Pakistan and used for biosurfactant production. Optimized media for biosurfactant production was at $(6 \% \mathrm{w} / \mathrm{v})$ white beans powder in combination with $(1.5 \% \mathrm{w} / \mathrm{v})$ waste frying oil and $(0.1 \% \mathrm{w} / \mathrm{v})$ urea that shows surface tension reduction $(28.8 \mathrm{mN} / \mathrm{m})$, oil displacement assay $(4.9 \mathrm{~cm})$ and emulsification index $(69.8 \%)$. Environmental growth parameters like temperature $\left(30{ }^{\circ} \mathrm{C}\right)$, inoculum size (1\%), pH (6) and agitation (150 rpm) exhibit important role towards enhanced biosurfactant yield. Furthermore, surfactin obtained was found to be most stable at $(5-7) \mathrm{pH},(8 \%) \mathrm{NaCl}$ and $\left(100{ }^{\circ} \mathrm{C}\right)$ temperature. Biosurfactant obtained was of lipopeptide nature called surfactin characterized by thin-layer chromatography (TLC) and fourier-transform infrared spectroscopy (FTIR). The surfactin obtained, used in a concentration of ( $0.7 \mathrm{~g} / 100 \mathrm{~mL})$ helps in seed germination and significantly enhanced growth of Solanum lycopersicum (tomato), Pisum sativum (pea), Capsicum annuum (peppers) and Lactuca sativa (lettuce).

Conclusions: Bacillus subtilis SNW3 produces surfactin with more stability, that makes it useful for processing of food and in agriculture. The use of white beans powder and waste frying oil as sole source of carbon and energy makes the biosurfactant production more profitable, and environment friendly procedure by utilizing food processing by-products and wastes as substrate. Results obtained provide understanding about surfactin use for seed development and plant growth.

\section{Background}

Surface-active compounds (surfactants) are amphiphilic compounds that constitute hydrophilic and lipophilic moieties. These dual characteristic molecules possess ability to reduce surface tension between solids, liquids, and gases interface. Chemical structure of surfactants confers desired properties; used widely in detergency, emulsifiers, dispersants, foaming and wetting agents, which increase annual production of surfactants over 15 million tons annually [1, 2]. Commercial production of surfactants based on precursors obtained from petrochemicals, plants and animal fats [3,4]. Wide use of petrochemical based surfactants results in release of toxic compounds in environment which settled down as contaminant in soil and water and penetrates into trophic chain causing danger to human health and all other living organisms $[5,6]$. The demand of environment friendly, biodegradable and sustainable green products needs new strategies development for replacement of synthetic surfactants with valuable biosurfactants [7, 8]. Generally, biosurfactants are derived from both plants and microorganisms and their structure consists of hydrophobic and hydrophilic moieties. In line with their chemical structure biosurfactants are classified into five groups: (I) Lipopeptides, (II) Glycolipids, (III) Fatty Acids, Neutral Lipids and Phospholipids, (IV) Polymeric Surfactant and (V) Particulate [9, 10]. However, as compared to plant-based surfactants biosurfactants from microorganisms has more useful multifunctional properties of highly biodegradable in nature, stability at high temperature and negligible effect on environment. Biosurfactants with numerous useful applications led to increasing interest in diverse industrial sectors of food, medicine, cosmetic and agriculture [11].

However, still production cost is high that depends on availability of raw materials, potential feedstock shortage, downstream processing that act as technological limitations in scaleup of biosurfactant production at industrial level $[12,13]$. Unlike synthetic surfactants that produced from petroleum feed stock, biosurfactants could be produced using waste materials as substrate like agriculture waste (wheat bran), brewery waste and food waste by-products (potato peels and waste frying oil) that could be use as carbon source that not only reduce cost but also helps in waste disposal in environment friendly manner $[14,15]$.

Surfactin, a lipopeptide nature of biosurfactant produced by Bacillus subtilis strains, is known for more promising features among all other biosurfactant molecules. Lipopeptides produced by Bacillus sp. with broad range of applications in biotechnology shows antiviral, antimicrobial, anti-tumour activities and exhibits a high emulsifying activity. An issue of interest nowadays is about increase in human population worldwide that accelerates food demands and agricultural productivity. In agriculture field lipopeptides not only provoke induced systemic resistance (ISR) to provide defence responses for eradicating plant pathogens but also increase the bioavailability of nutrient for helpful plant related microbes [16]. One of positive influence of use of lipopeptides in agriculture is its biocompatibility that do not accumulate in living organisms' tissues [17]. Biosurfactants can broadly be applied to develop better quality of agricultural land through bioremediation of soil and increase in biogenic substances solubility. Accomplishment of fertilizers and pesticides distribution equally in heavy soil is made possible through hydrophilization with use of biosurfactants. Phenomena of pre-sowing and seed stimulation that accelerates germination through natural-based products like biosurfactants got worldwide attention because of its ecological approach. These stimulants covered seed surfaces with prominent molecules that keep seeds protected against microbial attack and enhance seed metabolism for resistance against fungi, bacteria, virus and yeasts. The initial dose of fertilizer in agricultural activities could be reduced through seed stimulation [18]. Thus, investigation about use of biosurfactant for exploring their role in seed development, promotion of plant growth and other applications needed details research.

The aim of our research study was optimization of biosurfactant production by Bacillus subtilis SNW3 by using cost effective substrates (white beans powder, potatoes peels powder, molasses and waste frying oil), chemical characterization of surfactin obtained and to evaluate the effect of biosurfactants on seedling germination and growth. Present study explores the impact of surfactin on Solanum lycopersicum (tomato), Capsicum annuum (peppers), Pisum sativum (pea) and Lactuca sativa (lettuce). The seeds of all these vegetables are rich in carbohydrates, protein, fats, and vitamins that makes them highly nutritious and easy to grow for experiments on lab scale. 


\section{Materials And Methods}

\section{Microorganism and culture conditions}

In current study, Bacillus subtilis SNW3, obtained from Microbiology Research Lab, Quaid-i-Azam University, Islamabad, previously identified and isolated from contaminated soil of Fimkessar oil field, Chakwal, Pakistan [19]. Bacterial sample was cultured on nutrient agar plates (Yeast extract 2.0; Beef extract 1.0; Peptone 5.0; Sodium chloride 5.0; Agar $15 \mathrm{~g} / \mathrm{L}$ ) incubated for $24 \mathrm{~h}$ at $30^{\circ} \mathrm{C}$ to obtain separate pure colonies, stored for regular use at $4{ }^{\circ} \mathrm{C}$ and sub-cultured before use. The strain was preserved at $-80^{\circ} \mathrm{C}$ in nutrient broth (Peptone, 5; Meat extract, 1; Yeast extract, 2.0 and sodium chloride g/L) supplemented with $30 \%$ glycerol.

\section{Cost effective substrates and medium optimization for biosurfactant production.}

For biosurfactant production optimization by Bacillus subtilis SNW3 various cost-effective substrates as carbon sources ( $2 \%$ w/v) were screened out as substrate: potato peels powder (Total soluble sugar 1\%; Total carbohydrate 68.7\%; Starch 52.14\%; Protein 8\%; Fat 2.6\%; Ash 6.34\%; Nitrogen 1.3\%), molasses (Total sugar 46.2\%; Sucrose 45.9\%; Protein 11\%; Lipid 0.7\%; Ash 9.8\%), white beans powder (Protein 15-30\%; Carbohydrates 60-70\%; Lipids 0.7-2\%) and waste frying oil (Palmitic acid 29.75\%; Oleic acid 34.01\%; Stearic acid 3.08\%; Linoleic acid $28.85 \%$ ) and nitrogen sources: sodium nitrite, urea and ammonium nitrate $(0.1 \% \mathrm{w} / \mathrm{v})$ while yeast extract (Protein $62.5 \%$; Sugar $2.90 \%$; Fat $0.10 \%$; Ash $9.50 \%)$ was used as control media. Each carbon source listed above was tested individually as alternative substrate for yeast extract, then impact of selected substrates was tested in different combinations at different ratios for achievement of an optimized medium composition. Molasses used for experiment was obtained from Chashma Sugar Mills Limited in Dera Ismail Khan (Pakistan). Potato peels and waste frying oil were obtained from café located at Quaid-i-Azam University Islamabad (Pakistan). White beans were obtained from National Agricultural Research Council (NARC) Islamabad Pakistan and were grinded to be used in powdered form.

\section{Inoculum}

Bacillus subtilis SNW3, streaked and stored on nutrient agar plates at $4{ }^{\circ} \mathrm{C}$ was used for inoculum preparation. A loop full of culture from single isolated colony on plate added in $100 \mathrm{~mL}$ nutrient broth (Peptone, 5; Meat extract, 1; Yeast extract, 2.0 and sodium chloride, $5 \mathrm{~g} / \mathrm{L}$ ) incubated at $30{ }^{\circ} \mathrm{C}$ for $48 \mathrm{~h}$. About $2 \%$ seed culture from nutrient broth was used as inoculum for all experiments.

\section{Biosurfactant production}

The substrates used to be screened out were weighted and sterilized separately into $250 \mathrm{~mL}$ Erlenmeyer flask through autoclaving at $121{ }^{\circ} \mathrm{C}$ for $1 \mathrm{~h}$ aimed to remove microbial spores and then cooled before use. Then mineral salts medium (MSM) as described by Abouseoud et al. [20] with given composition ( $\mathrm{g} / \mathrm{L}$ ): $\mathrm{KH}_{2} \mathrm{PO}_{4}, 2.0 ; \mathrm{K}_{2} \mathrm{HPO}_{4}, 4.0 ; \mathrm{FeSO}_{4} .7 \mathrm{H}_{2} \mathrm{O}, 0.025 ; \mathrm{MgSO}_{4} .7 \mathrm{H}_{2} \mathrm{O}, 1.0 ; \mathrm{KCl}, 0.2 ; \mathrm{NaCl}, 5.0 ; \mathrm{CaCl}_{2} .2 \mathrm{H}_{2} \mathrm{O}, 0.02$; and trace elements solution of $0.1 \mathrm{~mL}$ containing g/L: $\mathrm{MnSO}_{4} .4 \mathrm{H}_{2} \mathrm{O}, 1.78 ; \mathrm{ZnSO}_{4} .7 \mathrm{H}_{2} \mathrm{O}, 2.32 ; \mathrm{CuSO}_{4} .5 \mathrm{H}_{2} \mathrm{O}, 1.0 ; \mathrm{H}_{3} \mathrm{BO}_{3}, 0.56 ; \mathrm{KI}, 0.66$ and $\mathrm{NH}_{4} \mathrm{MoO}_{4} .2 \mathrm{H}_{2} \mathrm{O}, 0.39$ (chemicals used were purchased from Sigma (SigmaAldrich ${ }^{\circledR}, \mathrm{USA}$ ), $\mathrm{pH}$ adjustment up to $7.0 \pm 0.2$ was added to the substrate to enrich production medium. To this production medium $2 \%$ bacterial seed culture was inoculated, mixed carefully, and put in shaker incubator for 4 days at $150 \mathrm{rpm}$ and $30^{\circ} \mathrm{C}$ temperature. After incubation for 4 days, fermentation broth was centrifuged $\left(12,000 \mathrm{rpm}, 20 \mathrm{~min}, 4^{\circ} \mathrm{C}\right)$ to obtain cell free supernatant that was extracted as described by Santos et al. [21]. Mean value for analysis was considered because all experiments performed were in triplicates.

\section{Culture conditions optimization for biosurfactant production}

After screening and optimization of carbon nitrogen substrates effect of environmental process parameters significant for biosurfactant production were evaluated. Effect of temperature (15, 30, 37 and $\left.50{ }^{\circ} \mathrm{C}\right), \mathrm{pH}(2,4,6,8,10,12)$, agitation speeds $(0,150$ and $250 \mathrm{rpm})$ and inoculum size $(0.5,1,1.5,2$ and $2.5 \%)$ was evaluated. While evaluating effect of one parameter other parameters were keep constant. After optimizing medium and cultural conditions $1 \mathrm{~L}$ shake flask fermentation experiment was set to reveal production that replace yeast extract.

\section{Assessment of biosurfactant production}

For qualitative and quantitative analysis of biosurfactant that was produced after 4 days cell free supernatant of production medium was obtained after centrifugation at 12,000 rpm for 20 minutes. The Oil Displacement Activity (ODA) test was performed according to Morikawa et al. [22] by placing cell free supernatant of $10 \mu \mathrm{L}$ was placed gently on uniform crude oil layer formed on distilled water surface of $40 \mathrm{~mL}$ in $15 \mathrm{~cm}$ petri dish. Oil layer was displaced, and clear zone diameter was measured in centimetre $(\mathrm{cm})$ with production medium without inoculum was used as negative control. Emulsification index (E24\%) was used to evaluate emulsifying activity of produced biosurfactant according to protocol of Cooper and Goldenberg [23]. Kerosene oil (2 $\mathrm{mL})$ and an equal volume of cell-free supernatants in test tube were mixed for 2 minutes on the vertex mixer and placed for 24 hours undisturbed at room temperature measured using given formula where heights were calculated in centimetres $(\mathrm{cm})$ [15].

$$
\mathrm{E}_{24}(\%)=\frac{\text { Height of the emulsion }(\mathrm{cm})}{\text { Total height of the solution }(\mathrm{cm})} \times 100
$$

Surface tension (SFT) of cell free supernatant was determined to analyze interface properties of produced biosurfactant by using KRUSS K20 digital Tensiometer (Kruss $\mathrm{GmbH}$, Hamburg, Germany), wilhelmy plate method was used according to protocol given by manufacturer by using a platinum plate. The SFT was measured in $\mathrm{mN} / \mathrm{m}$ and performed at room temperature.

\section{Surfactin extraction}


Surfactin extraction was conducted as earlier described by Lovaglio et al. [24]. The cell-free broth was obtained after centrifugation at $4{ }^{\circ} \mathrm{C}$ and 10,000 rpm for 20 minutes. Concentrated $(\mathrm{HCl})$ was used to acidify supernatant at $\mathrm{pH} 2.0$ and kept in refrigerator for overnight at $4{ }^{\circ} \mathrm{C}$. After acidification again liquid was centrifuged for 20 minutes at 10,000 rpm to obtain pelleted precipitates. For crude surfactin equal volumes of pelleted precipitates and chloroform/methanol (2:1) methanol were mixed thoroughly in a volumetric flask to separate organic and aqueous phase. Extraction was done thrice for maximum surfactin recovery that was concentrated by rotary evaporation [25].

\section{Chemical characterization of surfactin produced.}

Crude surfactin obtained after extraction was analyzed by thin-layer chromatography (TLC) where surfactin (sigma) was taken as standard. Crude biosurfactant components were separated on Silica coated aluminum plates, silica gel 60 F254, MERCK Germany using Chloroform: Methanol: acetic acid $(85: 10: 5, v / v)$. Plate was developed, dried, and visualized under UV light of $254 \mathrm{~nm}$ for fluorescence quenching spots and $365 \mathrm{~nm}$ wavelengths for fluorescent spots and retention factor (Rf) values were compared [26]. Fourier transform infrared spectroscopy (FTIR) was used to determine chemical nature of functional groups and bonds present in crude biosurfactant with use of Tensor 27 (Bruker) FTIR spectrophotometer, equipped with ZnSe ATR. For analysis solid form of crude extracted surfactin (10 mg) was loaded and spectrum and observed at the range of $4500-450 \mathrm{~cm}^{-1}$ [27]. Spectrum of surfactin (Sigma) was used as standard for determination of surfactin type of biosurfactant produced and to infer the nature of functional groups and chemical bonds in extracted surfactin.

\section{Surfactin analysis, critical micelle concentration (CMC) and critical micelle dilution (CMD) determination}

For determination of $\mathrm{CMC}$ of crude extracted surfactin different concentrations $(0.06-1.24 \mathrm{mg} / \mathrm{mL})$ of surfactin were prepared in demineralized water, and the Surface tension (SFT) of each extract was measured up to a constant value of surface tension obtained by using KRUSS K20 digital Tensiometer at $25{ }^{\circ} \mathrm{C}$. For determination of $\mathrm{CMC}$ surface tension was plotted as logarithm function of concentration of biosurfactant and point of intersection was obtained between these two factors [28]. For critical micelle dilution cell free supernatant produced by Bacillus subtilis SNW3 after $96 \mathrm{~h}$ cultivation under optimized condition was diluted 10-folds up to three levels (i.e. 10x, 100x, and 1000x). These dilutions were named as $C M D^{-1}, C^{-2} D^{-2}$ and $C M D^{-3}$, respectively, and were analyzed by surface tension reduction values using wilhelmy plate method through tensiometer (EasyDyne K20, KRUSS, Germany).

\section{Functional characterization by Antibiogram of surfactin produced.}

Antbiogram activity of partially purified surfactin was analyzed by preparing Meuller Hinton Agar (MHA) media plates that were swabbed with multi drug resistant (MDR) Escherichia coli and treated with surfactin and two different antibiotics namely, ciprofloxacin and clarithromycin. Surfactin concentration of $(10 \mathrm{mg} / \mathrm{mL})$ was tested with ciprofloxacin and clarithromycin $(1 \mathrm{mg} / \mathrm{mL})$ and surfactin and antibiotics used in combination of (5:0.5) respectively. Dilutions of each tested surfactin and antibiotics made at given concentration and were poured in wells up to $100 \mu$ l of each dilution. After that plates were kept for incubation time of 24 hours at $37^{\circ} \mathrm{C}$ and diameter of clear zone around wells was measured.

\section{Surfactin stability at different environmental factors}

Stability testing for biosurfactant produced was examined at various ranges of temperature, $\mathrm{pH}$ and salt concentration [29]. Standard solutions of crude biosurfactant $(600 \mathrm{mg} / \mathrm{L})$ were prepared and distilled water was used as control stability test was performed by measuring surface tension at room temperature. For thermal stability analysis, standard solution of biosurfactant was incubated at different temperatures $\left(20-121^{\circ} \mathrm{C}\right)$ for 1 hour then surface tension of test solutions was measured after cooling at room temperature. Different concentrations of sodium chloride $\mathrm{NaCl}$ (1-10\%) was added to standard surfactin solution and incubated at $30^{\circ} \mathrm{C}$ for 1 hour followed by stability test. For pH effect on surfactin activity different buffer solutions, adjusted to $\mathrm{pH} 1-5$ using citrate-phosphate buffer, $\mathrm{pH} 7$ using phosphate buffer, and pH 9-11 using carbonate-bicarbonate buffer solutions and check for surface tension reduction after incubation at room temperature for 30 minutes.

\section{Seeds and germination experiments}

Seeds of Tomato (Solanum lycopersicum), Pea (Pisum sativum), Peppers (Capsicum annuum) and Lettuce (Lactuca sativa) were used for evaluation of surfactin effect on germination of seedlings. Seed were obtained from National Agricultural Research Centre (NARC) (Islamabad, Pakistan) and suppliers gave information about germination of seeds. Seed's germination was confirmed in laboratory by measuring radicles length and were regarded as germinated when longer than $3 \mathrm{~mm}$. Sterilization of seed coat from fungal pathogens was done while keeping seeds first for 20 minutes in $10 \%$ Na-hypochlorite and then washed with distilled water before use. For seed germination using petri plate forty number of seeds having same size and no observable damage were used and all experiments were done in triplicates. Petri plates (100 mm diameter) were covered with filter paper and cotton that were soaked with four different concentrations of surfactant solutions prepared i.e; $0.1,0.3,0.5$ and $0.7 \mathrm{~g} / 100 \mathrm{~mL}$ with $100 \% \mathrm{v} / \mathrm{v}$ distilled water was used as a control. Plates were kept in yellow light at $25^{\circ} \mathrm{C}$ covered with parafilm to prevent loss of moisture [30]. Number of all grown seeds after seven days was observed to conclude the rate of germination of seeds. Germination of seeds (Percentage number of seeds germinated) was valued as the seeds percentage that grown comparative to the other total seeds number (those that were died and deformed are of not germinated and excluded). The measurement of seeds was done by using a calliper gauge and the root and stem lengths $(\mathrm{mm})$ of all germinated seeds were measured. The root and shoot length sum were called as seedling length. The germinated seeds were counted on daily basis. (a) Relative seed germination (G, \%): (No. of seeds germinated (treatment) / No. of seeds germinated (control)×100); (b) Relative dry biomass (B, \%): (Mean dry biomass (treatment) / Mean dry biomass (control) $\times 100)$; (c) Relative root growth (L, \%): (Mean root length (treatment) / Mean root length (control) $\times 100$ ) and (d) Relative plant height: Mean height of plant (treatment) / Mean plant height (control) $\times 100)$ respectively of the control water $\left(\mathrm{H}_{2} \mathrm{O}\right)$. All germinated seeds were transferred in pots filled with sand, soil, and coarse-grained grit and put separately in pots to observe seeds germination strength for growing plants. These pots were placed in greenhouse with temperature changing between $20^{\circ} \mathrm{C}$ to $22^{\circ} \mathrm{C}$ and $\mathrm{L} / \mathrm{D}$ 16:8. Seeds without pre-treatment with surfactin was applied as control. Seed stimulation for planting was done with addition of biopreparation containing 
surfactin dissolved in distilled water at different given concentrations added in pots i-e $0.1,0.3,0.5$ and $0.7 \mathrm{~g} / 100 \mathrm{~mL}$ and distilled water as control. For each pot applying water every third day and after 40 days emergence of seed plant seedling was tested and checked for morphological characteristic of plants like shoot length, root length and dry weight of plants.

\section{Statistical Analysis}

The obtained results were analysed statistically with use of STATISTICA software, one-way ANOVA (version 8.1). The measured weight and height of plants were found and used for surfactin impact on stimulation and germination of all seeds used in study. Difference between obtained results were analysed by using Tukeys test to find individual and control mean \pm standard deviation. Significance value was set at $p=0.05$ and $p$-values $\leq 0.05$ were considered significant.

\section{Results And Discussion}

\section{Screening and optimization of cost-effective substrates for biosurfactant production}

Bacillus subtilis SNW3 was previously studied for biosurfactant production using yeast extract as sole source of carbon while in current study conducted number of $\mathrm{C} / \mathrm{N}$ sources (as mentioned above in methods) were used to enhance the biosurfactant yield. Major type of products produced by this isolate is identified as surfactin in form of C13-, C14-, and C15-surfactin mixture possess applicability in oil recovery [31] and as promising anti-tumour agent [32]. By introducing nitrogen containing compounds urea and yeast extract that exhibits amine groups bring about synthesis of biosurfactants having peptide moieties or enzymes that regulate the synthesis. In current study among nitrogen sources tested preferably urea act as good nitrogen source shows surface tension reduction $31.4 \mathrm{mN} / \mathrm{m}$ and of $2 \mathrm{~cm}$ (Fig. 1b). It has been reported that supplementation of peptone, urea, sodium nitrate, ammonium nitrate [33] and meat extract [34] increased biosurfactant production. Use of ammonium sulphate ( $5 \mathrm{~g} / \mathrm{L})$ and yeast extract ( $2 \mathrm{~g} / \mathrm{L})$ as nitrogen sources for biosurfactant production was also investigated by [35]. In current study yeast extract was used as control media and selected substrates as carbon sources includes white beans powder, potato peels powder, molasses, and waste frying oil ( $2 \%, \mathrm{w} / \mathrm{v})$ were checked for biosurfactant production after $96 \mathrm{~h}$. While single use of these substrates checked for surfactin production by surface tension reduction, emulsification and oil displacement activity shown in Fig. 1a. According to results obtained for $2 \%$ potato peels powder and white beans powder individually gave oil displacement value of 1.3 and $2.4 \mathrm{~cm}$ with surface tension reduction 41.3 and $33.6 \mathrm{mN} / \mathrm{m}$ and E24 55.1 and 57\% respectively. Application of cost-effective substrates for biosurfactant production reduce cost of enzymes production on industrial scale. Hence, ideal fermentation medium selection plays an important role for reducing cost of biomolecules [36]. Potato processing produce starch rich waste in form of potato peels, starch rich wastewater and unconsumable potato parts that could be used as substrate for microbial production [37]. Ohno and coworkers [38] investigated use of okara obtained after processing of ground soybeans as substrate for lipopeptide iturin and surfactin production by Bacillus subtilis NB22. Faiza et al. [39] reported use of potato peels for biosurfactant production by DGEF01-06 bacterial strains among which DGEF02 shows highest emulsification value of $70 \%$ while in current study conducted $55.1 \%$ emulsification was observed with $2 \%$ of potato peels waste. In this study, sugar cane molasses and waste frying oil individually indicated maximum E24 of up to 55.3 and $56.3 \%$, ODA i-e 0.9 and $1.8 \mathrm{~cm}$ with SFT 41 and 38.2 $\mathrm{mN} / \mathrm{m}$. It was previously reported that use of waste frying oil as sole source of carbon and energy lipopeptide production by two Bacillus strains that reduce surface tension up to $36 \mathrm{mN} / \mathrm{m}$ these results are consistent with our study that Bacillus strain used produce surfactin while growing on $2 \%$ waste frying oil reduce surface tension up to $38 \mathrm{mN} / \mathrm{m}$ [40]. De Lima et al. [41] reported rhamnose production by Pseudomonas aeruginosa PACL strain cultivating on waste frying soybean oils results indicate biosurfactant production with $100 \%$ emulsification index, surface tension reduction up to $26.0 \mathrm{mN} / \mathrm{m}$ and concentration of $3.3 \mathrm{~g} / \mathrm{L}$ while in current study $56.3 \%$ emulsification was observed with $2 \%$ waste frying oil. Molasses are co-product obtained from sugar beet and sugar cane industry that are widely used as substrate because of presence of vitamins and other valuable compounds in low cost. Molasses contains various compounds that includes sugars (sucrose 48-56\%), non-sugar organic matter (9-12\%), inorganic components, proteins and vitamins [42]. Research conducted by Abdel-Mawgoud et al. [43] investigate surfactin production in a cost effective manner with use of $16 \%$ molasses and other trace elements that produce surfactin yield of $1.12 \mathrm{~g} / \mathrm{L}$. However, it is also stated in many studies that the presence of hydrophobic substrate is essential for production of biosurfactants [44]. In present study, white beans powder and waste frying oil shows improved production of biosurfactant as compared to other substrates tested. Out of all media white beans powder and waste frying oil have good impact on biosurfactant production. Urea and ammonium nitrate have been already used and reported in literature as very cost-effective nitrogen source to produce biosurfactant by Artherobacter paraffineus and various other bacterial species [44]. Beans are considered as rich source of carbohydrates that were further used at different concentration with waste frying oil. Zhu et al. [45] reported use of soybean flour as substrate for surfactin production by Bacillus amyloliquefaciens XZ-173.

According to literature different types of oils e.g., vegetable oils, waste cooking oil, glycerol, glucose and diesel has been used as substrate for production of biosurfactant by a fungal species $M$. circinelloides $11.7 \mathrm{~cm}$ ODA showed maximum biosurfactant production by utilizing waste cooking oil as a carbon source [46] showed that $8 \%(\mathrm{v} / \mathrm{v})$ WCO, biosurfactant production by $M$. circinelloides was maximum and lesser at higher concentration $10 \%(\mathrm{v} / \mathrm{v})$ at 72 hours. It has also been reported in literature that Pseudomonas aeruoginosa undergoes productive yield of biosurfactant by using waste cooking oil. In present research white beans powder, waste frying oil and urea was used in different concentrations collectively Fig. 1c. Results obtained showed that the concentrations of white beans powder $6 \%$ with combination of waste frying oil $1.5 \mathrm{~mL}$ and urea $0.1 \mathrm{~g}$ showed significantly maximum surfactin yield indicated improved oil displacement value of (from 2.4 to $4.9 \mathrm{~cm}$ ) maximum emulsification index (from 57 to $69.8 \%$ ) and lowest surface tension reduction of (from 33.6 to 28.8 $\mathrm{mN} / \mathrm{m}$ ) Fig. 1c. In previous studies molasses and cheese whey were used in combination by four strains of Bacillus subtilis reduce the surface tension of medium up to 34 to $37 \mathrm{mN} / \mathrm{m}$ [47]. The results obtained in present study while using combination of white beans powder and waste frying oil were more significant lowers SFT up to $28.8 \mathrm{mN} / \mathrm{m}$ as compared to results described by Joshi et al., [47]. It was reported by Zhu et al. [48] that cell free supernatant based on glycerol produced by $B$. subtilis N3-4P, showed $27.8 \mathrm{mN} / \mathrm{m}$ surface tension and $38.3 \%$ emulsification index value in case of emulsifier not good results were obtained while comparing values with current study conducted. It's conferred by Cooper and Goldenberg [23] that if surface tension value is reduced up to $40 \mathrm{mN} / \mathrm{m}$ or below it could be regarded as efficient biosurfactant producer. These reported results give indication about Bacillus subtilis SNW3 as efficient biosurfactant producer. Different environmental habitats like hydrocarbon contaminants, marine and terrestrial environment, reported Bacillus 
species and related genera as Aeribacillus sp., B. licheniformis and Bacillus subtilis etc. for biosurfactant production [49, 50]. However, until now no reports are showed by Bacillus nealsonii strains for biosurfactant production. Study conducted by Medeot et al. [51] showed high yield of biosurfactant (1.7 mg/mL) while using $\mathrm{NH}_{4} \mathrm{NO}_{3}$ and glucose as substrate for production by Bacillus amyloliquefaciens $\mathrm{MEP} 218$. In the same way, combination of sucrose and $\mathrm{NH}_{4} \mathrm{NO}_{3}$ were used by Fernandes et al. [52] and they reported high yield of biosurfactant ( $0.2 \mathrm{~g} / \mathrm{L})$ by Bacillus subtilis RI4914. Likewise, study conducted for surfactin production by Abdel-Mawgound et al. [43] reported use of different carbon nitrogen sources and ultimate results showed maximum biosurfactant production by Bacillus subtilis BS5 while using $\mathrm{NaNO}_{3}$ and $\mathrm{NH}_{4} \mathrm{NO}_{3}$ as source of nitrogen. Obviously, source of nitrogen shows an important role for production of biosurfactant, but carbon/ nitrogen substrates combination has a crucial role in production.

For establishment of environmental parameters (temperature, $\mathrm{pH}$, agitation and amount of inoculum) were checked by oil displacement activity that significantly influence surfactin production (Fig. 2). It was observed that $30{ }^{\circ} \mathrm{C}$ temperature was the most suitable temperature for maximum biosurfactant production by Bacillus subtilis SNW3 shown in Fig. 2a. At $30{ }^{\circ} \mathrm{C}$ the clear zone of about $1.26 \mathrm{~cm}$ was observed that was also reported by Bonilla et al. [53] in their research for maximum biosurfactant production. In study reported by Bertrand et al. [54] Bacillus mycoides and Bacillus brevis strains were used for maximum biosurfactant production at temperature that ranges between $35-40{ }^{\circ} \mathrm{C}$. Though this temperature range is good for minimizing the production cost. According to Sahoo et al. [55] biosurfactant production by Pseudomonas aeruginosa OCD 1 is more efficient at $30^{\circ} \mathrm{C}$ temperature. Also, it was reported by Najafi et al. [56] that $30^{\circ} \mathrm{C}$ is the optimum temperature for biosurfactant production. These results are in correspondence with results obtained by our research. For monitoring inoculum size maximum production rate was observed with $1 \%$ inoculum size that gives a clear zone of $2.1 \mathrm{~cm}$ shown in Fig. $2 \mathrm{~b}$. On the other hand, inoculum size of $2 \%$ and $2.5 \%$ showed a very low yield of biosurfactant with a zone size of only $1.3 \mathrm{~cm}$ and $0.7 \mathrm{~cm}$. Inoculum size of $0.5 \%$ and $1.5 \%$ gives a zone of $1.6 \mathrm{~cm}$ and $1.9 \mathrm{~cm}$ of oil displacement zone. In current study at agitation $150 \mathrm{rpm}$ biosurfactant production was observed maximum ODA $1.2 \mathrm{~cm}$ as compared to other tested agitation speed shown in Fig. 2c. At static condition, no significant biosurfactant production was observed as wellknown importance of oxygenation for biosurfactant production, while with increase in rpm productivity of biosurfactant reduced that's also reported for Candida lipolytica [57]. However, at pH 6 high values for ODA of $2.1 \mathrm{~cm}$ were observed regarding optimization of biosurfactant production. Results obtained showed that $\mathrm{pH}$ of culture media have significant effect on biosurfactant production (Fig. 2d). At acidic condition productivity of biosurfactant reduced indicates that bacterial growth is sensitive to acidic conditions. Same in previous studies at pH 7 Stenotrophomonas maltophilia NBS-11 shows maximum production of biosurfactant [58].

To study surfactin production on optimized media and its growth kinetics at optimized conditions $\left(30^{\circ} \mathrm{C}, 150 \mathrm{rpm}, 1 \%\right.$ inoculum size, $\mathrm{pH} 6$, yeast extract $(2 \%$, $\mathrm{w} / \mathrm{v})$ and white beans powder, waste frying oil and urea $(6: 1.5: 0.1 \%, \mathrm{w} / \mathrm{v})$, in $1 \mathrm{~L}$ shake flask fermentation setup revealed a growth-associated production (Fig.1d) under optimum conditions shows maximum surfactin production with surface tension reduction value $28.5 \mathrm{mN} / \mathrm{m}, \mathrm{ODA} 5.53 \mathrm{~cm}$ emulsifying activity E24 $70.6 \%$, biomass $4.6 \mathrm{~g} / \mathrm{L}$, surfactin concentration of $1.17 \mathrm{~g} / \mathrm{L}$ attaining preferable media position to replace costly yeast extract media.

\section{Characterization of biosurfactant produced.}

Crude biosurfactant produced by Bacillus subtilis SNW3 was analyzed by thin-layer chromatography (TLC) that indicates product nature as lipopeptide surfactin with retention factor (Rf) value of 0.68 through band observed on plate in comparison to standard surfactin as illustrated in Fig. 3 . Likewise, Rf value of 0.76 was observed by [59] produced by Bacillus subtilis that indicates presence of surfactin. Similar results for Rf values were observed by [60] using Bacillus subtilis UMAF6619, UMAF6614, UMAF8561, UMAF6639 and Bacillus amyloliquefaciens PPCB004 for fengycin, iturin and surfactin as 0.9, 0.3 and 0.7 respectively. Similarly, Ramyabharathi and co-workers obtained results for surfactin and iturin production by Bacillus subtilis Bbv57 confirmed by TLC analysis showed Rf value for surfactin and iturin as 0.3 and 0.7 respectively making comparison with standard from Sigma-Aldrich [61]. In same way, YánezMendizábal and co-authors showed Rf value of 0.3 for surfactin and 0.7 for iturin [62]. Similar TLC pattern was observed by Joy et al. [26] obtained 0.55 and $0.72 \mathrm{Rf}$ values for lipopeptide nature of biosurfactants that was produced by Bacillus specie (SB2).

FTIR analyses of crude surfactin obtained showed presence of carboxylic functional groups and aliphatic amines that represent peptide bonds characteristic of lipopeptide biosurfactant nature. In current study Bacillus subtilis SNW3 showed various absorbance bands, characterized by aliphatic amines at $1023 \mathrm{~cm}{ }^{-1}$ and $972 \mathrm{~cm}^{-1}$ in standard surfactin (Fig. 4a) and crude biosurfactant (Fig. 4b) respectively resulting in stretching vibrations of C-N bonds. Moreover, bands formation at 1045.92 and $862.03 \mathrm{~cm}^{-1}$ are associated with stretching vibrations that are observed for glycosidic linkage [63]. At $1243 \mathrm{~cm}^{-1}$ and $1240 \mathrm{~cm}^{-1}$ in standard and sample respectively, in range of $1250-1020 \mathrm{~cm}^{-1}$ indicates presence of $\mathrm{C}-\mathrm{N}$ stretch aliphatic amines. Joshi et al. [47] also reported similar pattern of aliphatic and peptide moieties presence indicates lipopeptide biosurfactant nature. Peaks observed at 1453.40 and $1124.36 \mathrm{~cm}^{-1} \mathrm{suggest}$ about stretching bands between carbon atoms and hydroxyl groups in sugar moiety structure [54]. The $\mathrm{C}=0$ stretch mode of $1762 \mathrm{~cm}^{-1}$ and $1757 \mathrm{~cm}^{-1}$ among standard surfactin and crude extract respectively ranging from 1690-1762 $\mathrm{cm}^{-1}$ corresponds to ester carbonyl group characterized as peptide component also reported by Joshi et al. [47]. Likewise, stretch at $1721 \mathrm{~cm}^{-1}$ that indicates presence of lactone carbonyl group observed by Faria [64] in biosurfactant product produced by Bacillus subtilis isolate LSFM-05. The C-H stretch at $2942 \mathrm{~cm}^{-1}$, standard surfactin (Fig. 4a) and $2925 \mathrm{~cm}^{-1}$ in crude extract (Fig. 4b) were analysed as alkanes. Another peak ranging from $3500-3200 \mathrm{~cm}^{-1}$ gave indication about alcohols and phenols $\mathrm{O}-\mathrm{H}$ stretch, $\mathrm{H}-$ bonded presence. In current study absorption bands that are prominent obtained at $2925 \mathrm{~cm}^{-1}, 1240 \mathrm{~cm}^{-1}$ and $1378 \mathrm{~cm}^{-1}$ indicates about (CH2 and $\left.\mathrm{CH} 3\right)$ alkyl and aliphatic chains presence in biosurfactant. Another peak observed between $3800 \mathrm{~cm}^{-1}$ and $3100 \mathrm{~cm}^{-1}$ shows about $\mathrm{N}-\mathrm{H}$ and $\mathrm{C}-\mathrm{H}$ stretch vibrations in sample. The above results obtained are also reported previously in literature that presence of peptides and aliphatic hydrocarbons gives indication about lipopeptide class of biosurfactants [64].

\section{Critical micelle concentration (CMC) and critical micelle dilution (CMD) determination}

The critical micelle concentration (CMC) is the minimum biosurfactant concentration needed to achieve lowest surface tension value after that point micellar aggregates formation starts [65]. The surfactin from Bacillus subtilis SNW3 showed reduction in surface tension of water from 70 to $36 \mathrm{mN} / \mathrm{m}$ by increasing 
surfactin concentration with CMC value of $0.58 \mathrm{mg} / \mathrm{mL}$ (Fig. 5a). After that point increase in surfactin concentration did not result in more reduction in water surface tension, gave indication that the $\mathrm{CMC}$ had been obtained. These results were efficient as compared to commonly used synthetic surfactants sodium dodecyl sulfate (SDS), attains CMC value at $2100 \mathrm{mg} / \mathrm{L}$ [66]. The CMC value for partially purified surfactin obtained in current study that was found to be 580 $\mathrm{mg} / \mathrm{L}$ that was consistent with those previously reported for surfactin from Bacillus subtilis with CMC 200 and $1500 \mathrm{mg} / \mathrm{L}$ in cell free broth by using waste frying cooking oil as substrates reported by Oliveira and Garcia-Cruz, [67]. In present study CMC results were agreed with results obtained by Datta et al. [28] for biosurfactant produced by Bacillus subtilis MG495086. Estimation of surfactin concentration produced in medium could be done by critical micelle dilution. In current study surfactin produced seems to be more competent that remains stable with surface tension reduction values from $29 \mathrm{mN} / \mathrm{m}$ to 32 $\mathrm{mN} / \mathrm{m}$ after making 3-fold dilutions shown in Fig. 5b.

\section{Functional characterization of surfactin by antibiogram activity}

The antibiogram of surfactin produced by Bacillus subtilis SNW3 and antibiotics used against multi drug resistant Escherichia coli is shown in Fig. 6. Appearance of clear zone around well was monitored, and diameter $(\mathrm{mm})$ was calculated thrice to get mean value. It was observed that maximum inhibitory zone was with combined synergistic effect of surfactin with antibiotics used. Surfactin in combination with ciprofloxacin (Fig. 6a) and clarithromycin (Fig. 6b) displayed $30 \mathrm{~mm}$ inhibitory zone when used in combination in comparison to $27 \mathrm{~mm}$ for surfactin and 18 and $20 \mathrm{~mm}$ respectively when applied individually.

\section{Stability Studies}

After production of surfactin under optimum concentration, it was extracted in ethyl acetate and stability of surfactin was tested at different temperature, pH and salt concentrations that fluctuates depending on conditions. Surface tension reduction was used as an indicator to test stability of biosurfactant produced. Biosurfactant activity produced by Bacillus subtilis SNW3 was tested over various pH range $(1,3,5,7,9,11) \mathrm{pH}$ affects the stability at very lower and higher values. From pH 1 to 3 and above 7 the activity of surfactin was low as shown in Fig. 7. SFT values were good from pH 5 to 7 . However, the lowest surface tension value $(28.3 \mathrm{mN} / \mathrm{m})$ and achieved at $\mathrm{pH}$ 7. Decreased stability of surfactin at acidic $\mathrm{pH}$ could be due to precipitation of surfactin at lower $\mathrm{pH}$. Surfactin produced by Bacillus subtilis SNW3 was thermostable up to $100{ }^{\circ} \mathrm{C}$ at different temperature ranges, but was most stable at $40{ }^{\circ} \mathrm{C}$, so the surface tension of $28.9 \mathrm{mN} / \mathrm{m}$. Similarly, it was reported by Moussa and Azeiz [68] that only minor variations occurred in biosurfactant stability that was produced by Bacillus methylothrophicus and Rhodococcus equi strains while analyzed at temperature ranged between $20-120^{\circ} \mathrm{C}$. It was noticed by Hatef and Khudeir [69] while doing experiments on biosurfactant stability check produced by Pseudomonas putida PS6 that that biosurfactant produced remains stable in temperature ranged between $20-70{ }^{\circ} \mathrm{C}$, while after that with increase in temperature above $70{ }^{\circ} \mathrm{C}$ it starts to decrease in stability. Effect of salt concentration was observed by adding $\mathrm{NaCl}$ in different concentration $(1,2,4,6,8$ and $10 \%)$ into surfactin produced by all the three strains and best results were observed at $1-2 \%$ concentration of $\mathrm{NaCl}$ that shows lowest value of surface tension reduction at $30 \mathrm{mN} / \mathrm{m}$ while at higher salt concentration up to $8 \%$ decrease in stability of surfactin was observed. Reasons for decrease in stability of biosurfactant at increased $\mathrm{NaCl}$ concentration is due to ion-dipole interactions between salt and water which are stronger than interactions between salt and gaseous phase, that is avoid solute molecules to reach at interface to lowers surface tension. In a previous study conducted by Isty Adhitya Purwasena [70] biosurfactant produced shows good stability regarding emulsification at high temperature of $120^{\circ} \mathrm{C}$, pH of $4-10$ and $\mathrm{NaCl}$ concentration of $10 \%(\mathrm{w} / \mathrm{v})$ that are consistent with this study.

\section{Effect of biosurfactant produced on seed germination and plant growth.}

\section{Percent germination}

The analysis of the stimulation effect of surfactin on the seed germination ability was studied in the first step and then growth was studied. It was observed that in all seeds tested germinated better when applied with surfactin than in control. Solanum lycopersicum, Pisum sativum, Capsicum annuum and Lactuca sativa all showed good percent seed germination after seven days by increasing the concentration of surfactin (Fig. 9a, b). Better results were obtained at higher concentrations of surfactin than lower concentrations. All surfactin concentrations showed significant effect $(P<0.05)$ on seed germination of tomato, chilli, pea and lettuce seeds. The germination of Solanum lycopersicum seeds was not significantly affected at lower concentrations of surfactin tested, however at higher concentration $(0.7 \mathrm{~g} / 100 \mathrm{~mL})$ effect germination significantly. Among all seeds tested greatest stimulation was observed for Solanum lycopersicum seeds at $0.7 \mathrm{~g} / 100 \mathrm{~mL}$ concentration with percent germination of $68.75 \%$ in comparison to control water at which shows germination of $56.25 \%$. Among other seeds, there was also a significant difference in germination $(P<0.05)$ Fig. 8a. Among surfactin concentrations that were tested for Capsicum annuum it was observed that at lowest $(0.1$ and $0.3 \mathrm{~g} / 100 \mathrm{~mL})$ did not affect germination significantly in comparison to control. However, at high concentrations of surfactin $(0.5$ and $0.7 \mathrm{~g} / 100 \mathrm{~mL})$ there was significantly difference in number of seed germination. In Capsicum annum seeds, surfactin concentration of $0.5 \mathrm{~g} / 100 \mathrm{~mL}$ effect the germination percent of seeds $51.7 \%$ while compared with control MilliQ water that showed germination of $21.6 \%$. In contrast, among all seeds surfactant resulted in increase in germination percent, the Capsicum annum seeds showed significantly increase in germination speed almost double with respect to control MilliQ and at lower concentration of $0.5 \mathrm{~g} / 100 \mathrm{~mL}$ water grouped seeds Fig. 8a. Almost all surfactin concentrations verified accelerated germination of Pisum sativum seeds, with highest stimulation observe with increase in surfactin concentration that is at $0.7 \mathrm{~g} / 100 \mathrm{~mL}$, and percent germination of seeds on average were $37.2 \%$ as compared to control water that shows $19.43 \%$ Fig. 8 a. For Lacuta sativa, seed germination was significantly affected $(P<0.05)$ to some extent equally at all concentrations of surfactin added and there was not much difference in germination as compared to control. The experimental data about effect on seed germination and plant growth shown in (Table. 1).

Germination of seed begins after entrance of water in seed through seed coat, that helps in activation of metabolic processes in seed. Permeability of embryonic tissues is the key factor for water entrance [71] when applied on external wrapping tissues facilitate germination process by increasing seeds permeability, as described by [72] for surfactants and in present study reason for chilli seeds germination almost double to control at lower concentration could be due to improved permeability. Small cracks in the cuticle of the palisade layer cause soybean cultivars to display fast wicking, which is the layer responsible for the permeability of water in this species [73]. Evolutionary strategies of this species may enhance the permeability of tissues, therefore did not affect soybean germination. Diffusion of released nutrients at suitable rates is carried out by liquid-filled intercellular spaces in the seed coat as observed in 
current study among all species with addition of biosurfactant germination increase as compared to control could be due to more nutrients diffusion.

Penetration of rhamnolipids in soybean and sunflower seeds, help to mobilize oleaginous reserve tissue from these species, consequently supporting seedling development. Biopreparations are widely used in enhancement of seed quality these days. Application of biosurfactant to improve plant germination is mostly done on contaminated soil. Some of biopreparation are used as nutrients for plants and helps in germination [74]. Plants enrichment with nitrogen and stimulation of plants height are benefits of Azotobacter sp. Genus in planting crop seeds or for vaccination of roots seedling fertilizers. Increase in germination proportion for pea seeds was observed after treatment with surfactin. This synchrony of germination plays a key role in farming, at harvest time it reduces cost and optimize the producer work because plants were present at same development stage [75]. It was observed in this study that development of seeds varies and depends on cultivars type and concentration of surfactin used. Positive impact of surfactin use on seed germination and development of seedling aids in farming practices at sites that goes through bioremediation practices.

\section{Dry biomass}

After germination growth was second parameter to be observed. When evaluating the dry biomass of $L$. sativa and $C$. annum seedling it was observed that increase in surfactin concentration $(0.5$ and $0.7 \mathrm{~g} / 100 \mathrm{~mL})$ did not favoured greater accumulation of dry biomass while there was increase in biomass relative to control indicates mean weight of $0.24 \mathrm{~g}$ and $0.20 \mathrm{~g}$ at $0.7 \mathrm{~g} / 100 \mathrm{~mL}$ in comparison to control seedling of $0.055 \mathrm{~g}$ and $0.058 \mathrm{~g}$ respectively. Although a positive effect was noted for Pisum sativum seedling, addition of surfactin significantly increase $(P<0.05)$ dry biomass of $2.21 \mathrm{~g}$ at $0.7 \mathrm{~g} / 100 \mathrm{~mL}$ in relative to control MilliQ water Fig. 8b. In contrast while analysing Solanum lycopersicum seedling dry weight subjected to surfactin showed slight difference in values at all concentrations tested while there was increase in seedling dry biomass of $0.19 \mathrm{~g}$ at $0.7 \mathrm{~g} / 100 \mathrm{~mL}$ relative to control group $0.078 \mathrm{~g}$ was observed. Positive impact of surfactin on seedling germination was observed that indirectly also increase biomass of seedling analysed after treatments. As for rhamnolipids, the hypothesis is that lipopeptides have the ability to create some disturbance in the plant plasma membrane and could consequently activate a cascade of molecular events leading to the activation of defence mechanisms [76].

\section{Root length}

Almost all surfactin concentrations tested influenced root elongation. Surfactin concentration and root development are directly related, increase in surfactin concentration results in better development of root length. It was observed that higher concentration $0.7 \mathrm{~g} / 100 \mathrm{~mL}$ of surfactin enhance root growth at maximum. Surfactin effect root elongation more in $P$. sativum and $L$. sativa than other plant seeds tested. The root length of Lactuca sativa seeds that were stimulated with surfactin treatment showed somewhat increase with initial minimum concentration of surfactin while greater development of root length of $2.74 \mathrm{~cm}$ at $0.7 \mathrm{~g} / 100 \mathrm{~mL}$. In contrast while Pisum sativum seeds subjected to surfactin treatment the development of roots length increases in uniformly with increase in concentration showed $2.89 \mathrm{~cm}$ at $0.7 \mathrm{~g} / 100 \mathrm{~mL}$ relative to control. However, for Capsicum annum seeds it was noticed that at high concentration $(0.3,0.5,0.7 \mathrm{~g} / 100 \mathrm{~mL})$ had significant effect $(P<0.05)$ on elongation of root gave $1.87 \mathrm{~cm}$ at $0.7 \mathrm{~g} / 100 \mathrm{~mL}$ in comparison to control group seeds mean root length of $1 \mathrm{~cm}$. The use of surfactin for Solanum lycopersicum also increase root development seen with increase in surfactin concentration added Fig. 8c. Resistance of seed coating is main factor that limits the root axis extension for development of roots thus applying surfactin helps in decreasing strength of wrapping tissues that favour characterisation of germinate on through protrusion of radical [71]. While considering root length of lettuce seeds after application of surfactin at different concentrations it was observed that before root region leaf portion emerged therefore less growth was observed for root as compared to other seeds. This atypical leaf emergence before roots development is possibly due to more reduction of resistance in leaf axis region of seed coat.

\section{Height of plant}

Surfactant stimulation affects height of seedlings in comparison to control specimen (Fig. 9c). The stimulation impact on height of $C$. annum and $P$. sativum plants was revealed more and differ significantly $(\mathrm{P}<0.05)$ with increase in surfactin concentration as compared to control. The average height of $C$. annum and $P$. sativum plant increase $8.06 \mathrm{~mm}$ and $12.66 \mathrm{~mm}$ respectively at $0.7 \mathrm{~g} / 100 \mathrm{~mL}$ relative to control. When $L$. sativa plants were checked for height revealed at lower concentration of surfactin $(0.1 \mathrm{~g}$ and $0.3 \mathrm{~g} / 100 \mathrm{~mL})$ application was not much significant but at higher concentrations $(0.5 \mathrm{and} 0.7 \mathrm{~g} / 100 \mathrm{~mL})$ showed significant $(\mathrm{P}<0.05)$ increase as compared to control Fig. $8 \mathrm{~d}$. All results showed that seed germination is highly affected by adding various concentrations of surfactin and are significantly different relative to control, but plant growth was comparatively less by adding surfactin. It was demonstrated by these results that applying surfactin shows positive effect for plants tested and could be used in future for growing such species to replace use of synthetic surfactant. Research done for biosurfactant impact on growth of plant is not more. It is believed there is indirectly promotion of plant growth through microbial surfactants by increasing hydrophobic compounds bioavailability to microbes living in region of rhizosphere [25]. In a recent study conducted surfactin produced by Bacillus isolates studied about ISR (induced systemic resistance) inducer where a strong relationship was analyzed between concentration of surfactin use and induction of defence activity among plant that indicates that with increase in concentration of surfactin introduce to plant also increase in systemic resistance [77]. In this study at higher concentration from $0.5 \mathrm{~g} / 100 \mathrm{~mL}$ to $0.7 \mathrm{~g} / 100 \mathrm{~mL}$ of surfactin added there is a weaker stimulation in plant growth that may be due to increase in hydrophobic compounds present in environment, which makes difficult for rhizosphere microorganisms to assimilate all these compounds or through release of some inhibitory compounds from soil that results in growth inhibition of these microorganisms. About research for biosurfactants effect on plants development examine about heavy metals and hydrocarbon polluted environments. Our study creates opportunity for use of these biological surfactants for plant growth promotion in agricultural field in cost effective and environment friendly manner. However, some research gaps are still required to be filled for explanation of mechanism that shows effect of biological surfactants on plants growth and development. Biosurfactant induced different mechanism recommended for plant growth promotion like reduction in seed microflora [78] incidence increase in IAA phytohormones production [79] and increase in amylase activity [80] that helps in improvement of plant growth better option for development in agricultural field. 
Table 1: Statistical Mean (M), Std. Deviation (SD), Std. Error (SE) and P value for relative seed germination, dry biomass, root length and plant height at four different concentrations of biosurfactant produced by Bacillus subtilis SNW3 used for four different plant species.

\begin{tabular}{|c|c|c|c|c|c|c|c|c|c|c|c|c|c|c|c|c|c|}
\hline & & Control & & & & $0.1 \mathrm{~g}$ & & & & $0.3 \mathrm{~g}$ & & & & $0.5 \mathrm{~g}$ & & & \\
\hline & & $M$ & SD & SE & $\mathbf{P}$ & $M$ & SD & SE & $P$ & $M$ & SD & SE & $\mathbf{P}$ & $M$ & $S D$ & SE & $\mathbf{P}$ \\
\hline \multirow[t]{4}{*}{ Root length } & Chilli & 1.01 & .43 & .13 & .00 & .93 & .32 & .08 & .00 & 1.72 & .49 & .12 & .00 & 1.87 & .45 & .08 & .0 \\
\hline & Tomato & 2.15 & .46 & .08 & & 2.53 & .38 & .07 & & 2.67 & .42 & .074 & & 2.86 & .36 & .06 & \\
\hline & Pea & 1.56 & 1.05 & .26 & & 2.15 & .42 & .13 & & 2.45 & .36 & .11 & & 2.59 & .49 & .12 & \\
\hline & Lettuce & 1.50 & .29 & .51 & & 1.81 & .23 & .04 & & 1.91 & .34 & .06 & & 2.39 & .34 & .06 & \\
\hline \multirow{4}{*}{$\%$} & Chilli & 21.6 & 15.47 & 5.85 & .00 & 28.21 & 17.31 & 6.54 & .02 & 26.07 & 18.65 & 7.05 & .00 & 51.79 & 28.16 & 10.64 & .0 \\
\hline & Tomato & 56.25 & 24.69 & 10.08 & & 55.83 & 24.88 & 10.16 & & 62.50 & 24.19 & 9.87 & & 62.92 & 26.00 & 10.61 & \\
\hline & Pea & 19.43 & 13.25 & 5.49 & & 24.40 & 15.84 & 6.47 & & 29.42 & 13.42 & 5.48 & & 32.75 & 22.34 & 9.12 & \\
\hline & Lettuce & 20.50 & 12.93 & 5.28 & & 22.50 & 13.11 & 5.35 & & 25.83 & 12.82 & 5.23 & & 24.00 & 11.69 & 4.77 & \\
\hline \multirow[t]{4}{*}{ Plant height } & Chilli & 5.35 & .61 & .16 & .00 & 5.27 & .94 & .25 & .00 & 5.99 & .54 & .13 & .00 & 8.08 & .39 & .07 & .0 \\
\hline & Tomato & 5.97 & .66 & .12 & & 6.37 & .50 & .09 & & 6.92 & .43 & .08 & & 7.28 & .61 & .10 & \\
\hline & Pea & 10.62 & .32 & .12 & & 11.22 & .24 & .07 & & 11.54 & .39 & .11 & & 12.58 & .39 & .09 & \\
\hline & Lettuce & 5.26 & .61 & .12 & & 5.58 & .40 & .07 & & 5.73 & .37 & .06 & & 6.00 & .29 & .05 & \\
\hline \multirow{4}{*}{$\begin{array}{l}\text { Dry } \\
\text { biomass }\end{array}$} & Chilli & .06 & .02 & .01 & .00 & .07 & .03 & .01 & .00 & .14 & .03 & .01 & .00 & .20 & .03 & .00 & .0 \\
\hline & Tomato & .08 & .03 & .00 & & .11 & .02 & .00 & & .13 & .02 & .01 & & .16 & .03 & .005 & \\
\hline & Pea & 1.52 & .19 & .06 & & 1.68 & .18 & .06 & & 1.98 & .23 & .07 & & 2.02 & .26 & .07 & \\
\hline & Lettuce & .06 & .03 & .004 & & .06 & .02 & .004 & & .15 & .04 & .006 & & .23 & .06 & .01 & \\
\hline
\end{tabular}

\section{Conclusion}

In current study, Bacillus subtilis SNW3 a natural producer of biosurfactant isolated from contaminated soil of Fimkessar oil field, Chakwal, Pakistan. Media composition was optimized by testing several cost-effective substrates provided in different combinations for the enhanced production of biosurfactant by Bacillus subtilis SNW3. Surfactin obtained from this strain shows potential emulsifuing and surface tension reducing capabilities with strong stability towards different environmental factors i-e pH, Temperature, Salanity. Furthermore, TLC and FTIR analysis were carried out for confirmation of producing product as surfactin a lipopeptide class the biosurfactant. Surfactin application is favorable for the germination and growth of Solanum lycopersicum, Pisum sativum, Capsicum annuum and Lactuca sativa this combined with the high environmental compatibility of these biological molecules can lead to a new vision for possible use of surfactin as promoting agent for plant growth. Cost of biosurfactant production their effectiveness in field and compounds purity needs to be improved for improvement in crop protection at higher level. Furthermore, the surfactin produced by strain could be used in many other environmental applications.

\section{Declarations}

\section{Acknowledgements}

Authors are grateful and acknowledge the Higher Education Commission, Pakistan, for providing fnancial support for this study

\section{Funding}

No funding from external are received for this research

\section{Availability of data and materials}

Te data used to support the fndings of this study are available from the corresponding author upon request.

\section{Ethics approval and consent to participate}

No animals or human subjects were used in the above research.

\section{Consent for publication}

Our manuscript does not contain any individual data in any form. 


\section{Competing interests}

The authors declare that they have no competing interests.

\section{Authors contributions}

AU and SA, Conception and study design; $A U$ and AZ, carry out experimental work of study; AU, MPS and HW, testing and data analysis of study; SA, Supervision; $A U$ and $A Z$, draft the manuscript; $A U, Z A M$ and $S A$, revised the manuscript. All authors read and approved the final manuscript.

\section{Author details}

1 Department of Microbiology, Quaid-i-Azam University, Islamabad 45320, Pakistan

2 Department of Microbiology, University of Balochistan, Quetta 87300, Pakistan.

3 Department of Microbiology, Shah Abdul Latif University, Khairpur, Sindh 66111, Pakistan.

4 Department of Psychology, Quaid-i-Azam University, Islamabad 45320, Pakistan.

\section{References}

1. Naughton P, Marchant R, Naughton V, Banat IJJoam. Microbial biosurfactants: current trends and applications in agricultural and biomedical industries. 2019;127(1):12-28.

2. Marchant R, Banat IMJBI. Biosurfactants: a sustainable replacement for chemical surfactants? 2012;34(9):1597 - 605.

3. De Almeida DG, Soares Da Silva RdCF, Luna JM, Rufino RD, Santos VA, Banat IM, et al. Biosurfactants: promising molecules for petroleum biotechnology advances. 2016;7:1718.

4. Rampadarath S, Puchooa D, Bal SJEJoB. Repetitive element palindromic PCR (rep-PCR) as a genetic tool to study interspecific diversity in Euphorbiaceae family. 2015;18(6):412-7.

5. Olkowska E, Polkowska Ż, Namieśnik JJT. Analytical procedures for the determination of surfactants in environmental samples. 2012;88:1-13.

6. Scott MJ, Jones MNJBeBA-B. The biodegradation of surfactants in the environment. 2000;1508(1-2):235-51.

7. Ajala OE, Aberuagba F, Odetoye TE, Ajala AMJCR. Biodiesel: Sustainable Energy Replacement to Petroleum-Based Diesel Fuel-A Review. 2015;2(3):14556.

8. Shaban SM, Abd-Elaal AAJMS. C E. Studying the silver nanoparticles influence on thermodynamic behavior and antimicrobial activities of novel amide Gemini cationic surfactants. 2017;76:871-85.

9. Zhang Y, Wei J, Zhu Y, George-Ufot GJJoCP. Untangling the relationship between Corporate Environmental Performance and Corporate Financial Performance: The double-edged moderating effects of environmental uncertainty. 2020;263:121584.

10. Jiménez-Peñalver P, Castillejos M, Koh A, Gross R, Sánchez A, Font X, et al. Production and characterization of sophorolipids from stearic acid by solidstate fermentation, a cleaner alternative to chemical surfactants. 2018;172:2735-47.

11. Patil S, Pendse A, Aruna KJIJCB. Studies on optimization of biosurfactant production by Pseudomonas aeruginosa F23 isolated from oil contaminated soil sample. 2014;2(4):20-30.

12. Akbari S, Abdurahman NH, Yunus RM, Fayaz F, Alara ORJBR, Innovation. Biosurfactants-a new frontier for social and environmental safety: a mini review. 2018;2(1):81-90.

13. De S, Malik S, Ghosh A, Saha R. Saha BJRa. A review on natural surfactants. 2015;5(81):65757-67.

14. Vea EB, Romeo D, Thomsen MJPC. Biowaste valorisation in a future circular bioeconomy. 2018;69:591-6.

15. Moshtagh B, Hawboldt K, Zhang BJEt. Optimization of biosurfactant production by Bacillus subtilis N3-1P using the brewery waste as the carbon source. 2018.

16. Anjum F, Gautam G, Edgard G, Negi SJBt. Biosurfactant production through Bacillus sp. MTCC 5877 and its multifarious applications in food industry. 2016;213:262-9.

17. Ławniczak Ł, Marecik R. Chrzanowski ŁJAm, biotechnology. Contributions of biosurfactants to natural or induced bioremediation. 2013;97(6):2327-39.

18. Krawczyńska M, Kolwzan B, Rybak J, Gediga K, Shcheglova NSJPJoES. The Influence of Biopreparation on Seed Germination and Growth. 2012;21(6).

19. Malik Z, Ahmed SJAJoB. Degradation of petroleum hydrocarbons by oil field isolated bacterial consortium. 2012;11(3):650-8.

20. Abouseoud M, Yataghene A, Amrane A, Maachi, RJJolM. Biotechnology Biosurfactant production by free alginate entrapped cells of Pseudomonas fluorescens. 2008;35(11):1303-8.

21. Santos DKF, Meira HM, Rufino RD, Luna JM, Sarubbo LAJPB. Biosurfactant production from Candida lipolytica in bioreactor and evaluation of its toxicity for application as a bioremediation agent. 2017;54:20-7.

22. Morikawa M, Hirata Y, Imanaka TJBeBA-M, Lipids CBo. A study on the structure-function relationship of lipopeptide biosurfactants. 2000;1488(3):211-8.

23. Cooper DG, Goldenberg BGJA, microbiology e. Surface-active agents from two Bacillus species. 1987;53(2):224-9.

24. Lovaglio RB, da Silva VL, de Lucca Capelini T, Eberlin MN, Hausmann R, Henkel M, et al. Rhamnolipids production by a Pseudomonas eruginosa LBI mutant: solutions and homologs characterization. 2014;51(5):397-405.

Page $10 / 18$ 
25. Marchut-Mikolajczyk O, Drożdżyński P, Pietrzyk D, Antczak TJMcf. Biosurfactant production and hydrocarbon degradation activity of endophytic bacteria isolated from Chelidonium majus L. 2018;17(1):1-9.

26. Joy S, Rahman PK, Sharma SJCEJ. Biosurfactant production and concomitant hydrocarbon degradation potentials of bacteria isolated from extreme and hydrocarbon contaminated environments. 2017;317:232-41.

27. Marchut-Mikołajczyk O, Drożdżyński P, Januszewicz B, Domański J. Wrześniewska-Tosik KJJohm. Degradation of ozonized tire rubber by anilineDegrading Candida methanosorbosa BP6 strain. 2019;367:8-14.

28. Datta P, Tiwari P, Pandey LMJBt. Isolation and characterization of biosurfactant producing and oil degrading Bacillus subtilis MG495086 from formation water of Assam oil reservoir and its suitability for enhanced oil recovery. 2018;270:439 - 48.

29. Goswami M, Deka SJC, Biointerfaces SB. Biosurfactant production by a rhizosphere bacteria Bacillus altitudinis MS16 and its promising emulsification and antifungal activity. 2019;178:285-96.

30. Andriolo JL, Luz GLd, Witter MH, Godoi RdS, Barros GT, Bortolotto OCJHB. Growth and yield of lettuce plants under salinity. 2005;23(4):931-4.

31. Pereira JF, Gudiña EJ, Costa R, Vitorino R, Teixeira JA, Coutinho JA, et al. Optimization and characterization of biosurfactant production by Bacillus subtilis isolates towards microbial enhanced oil recovery applications. 2013;111:259-68.

32. e Silva NMPR, Rufino RD, Luna JM, Santos VA, Sarubbo LAJB, Biotechnology A. Screening of Pseudomonas species for biosurfactant production using low-cost substrates. 2014;3(2):132-9.

33. Thanomsub B, Watcharachaipong T, Chotelersak K, Arunrattiyakorn P, Nitoda T. Kanzaki HJJoam. Monoacylglycerols: glycolipid biosurfactants produced by a thermotolerant yeast. Candida ishiwadae. 2004;96(3):588-92.

34. Bednarski W, Adamczak M, Tomasik J, Płaszczyk MJBt. Application of oil refinery waste in the biosynthesis of glycolipids by yeast. 2004;95(1):15-8.

35. Lukondeh T, Ashbolt NJ. Rogers PLJJolM, biotechnology. Evaluation of Kluyveromyces marxianus Fll 510700 grown on a lactose-based medium as a source of a natural bioemulsifier. 2003;30(12):715-20.

36. Vijayaraghavan P, Arasu MV, Rajan RA, Al-Dhabi, NJSjobs. Enhanced production of fibrinolytic enzyme by a new Xanthomonas oryzae IND3 using lowcost culture medium by response surface methodology. 2019;26(2):217-24.

37. Fox SL, Bala GAJBt. Production of surfactant from Bacillus subtilis ATCC 21332 using potato substrates. 2000;75(3):235-40.

38. Ohno A, Ano T, Shoda MJB. bioengineering. Production of a lipopeptide antibiotic, surfactin, by recombinant Bacillus subtilis in solid state fermentation. 1995;47(2):209-14.

39. Ansari FA, Hussain S, Ahmed B, Akhter J, Shoeb EJIJBR. Use of potato peel as cheap carbon source for the bacterial production of biosurfactants. 2014;2:27-31.

40. Md Badrul Hisham NH, Ibrahim MF, Ramli N, Abd-Aziz SJM. Production of biosurfactant produced from used cooking oil by Bacillus sp. HIP3 for heavy metals removal. 2019;24(14):2617.

41. De Lima C, Ribeiro E, Servulo E, Resende M, Cardoso VJAB, Biotechnology. Biosurfactant production by Pseudomonas aeruginosa grown in residual soybean oil. 2009;152(1):156-68.

42. Maneerat SJSJST. Production of biosurfactants using substrates from renewable-resources. 2005;27(3):675-83.

43. Abdel-Mawgoud AM, Aboulwafa MM, Hassouna NA-HJAB, Biotechnology. Optimization of surfactin production by Bacillus subtilis isolate BS5. 2008;150(3):305-25.

44. Karanth N, Deo P, Veenanadig NJCS. Microbial production of biosurfactants and their importance. 1999:116 - 26.

45. Zhu Z, Zhang F, Wei Z, Ran W, Shen QJJoem. The usage of rice straw as a major substrate for the production of surfactin by Bacillus amyloliquefaciens $X Z-173$ in solid-state fermentation. 2013;127:96-102.

46. Hasanizadeh P, Moghimi H, Hamedi JJWS, Technology. Biosurfactant production by Mucor circinelloides on waste frying oil and possible uses in crude oil remediation. 2017;76(7):1706-14.

47. Joshi S, Bharucha C, Jha S, Yadav S, Nerurkar A. Desai AJJBt. Biosurfactant production using molasses whey under thermophilic conditions. 2008;99(1):195-9.

48. Zhu Y, Gan J-j, Zhang G-I, Yao B, Zhu W-j. Meng QJJoZU-SA. Reuse of waste frying oil for production of rhamnolipids using Pseudomonas aeruginosa zju. u1M. 2007;8(9):1514-20.

49. Chen Y, Liu SA, Mou H, Ma Y, Li M, Hu XJFim. Characterization of lipopeptide biosurfactants produced by Bacillus licheniformis MB01 from marine sediments. 2017;8:871.

50. Mehetre GT, Dastager SG, Dharne MSJSoTTE. Biodegradation of mixed polycyclic aromatic hydrocarbons by pure and mixed cultures of biosurfactant producing thermophilic and thermo-tolerant bacteria. 2019;679:52-60.

51. Medeot DB, Bertorello-Cuenca M, Liaudat JP, Alvarez F, Flores-Cáceres ML, Jofré EJBc. Improvement of biomass and cyclic lipopeptides production in Bacillus amyloliquefaciens MEP218 by modifying carbon and nitrogen sources and ratios of the culture media. 2017;115:119-28.

52. Fernandes P, Rodrigues E, Paiva F, Ayupe B, Mclnerney M, Tótola MJF. Biosurfactant, solvents and polymer production by Bacillus subtilis RI4914 and their application for enhanced oil recovery. 2016;180:551-7.

53. Bonilla M, Olivaro C, Corona M, Vazquez A, Soubes MJJoAM. Production and characterization of a new bioemulsifier from Pseudomonas putida ML2. 2005;98(2):456-63.

54. Bertrand B, Martínez-Morales F, Rosas-Galván NS, Morales-Guzmán D, Trejo-Hernández MRJC. Interfaces. Statistical design, a powerful tool for optimizing biosurfactant production: a review. 2018;2(3):36.

Page $11 / 18$ 
55. Sahoo S, Datta S, Biswas DJJASR. Optimization of culture conditions for biosurfactant production from Pseudomonas aeruginosa OCD1. 2011;2(3):326.

56. Najafi A, Rahimpour M, Jahanmiri A, Roostaazad R, Arabian D, Ghobadi ZJCEJ. Enhancing biosurfactant production from an indigenous strain of Bacillus mycoides by optimizing the growth conditions using a response surface methodology. 2010;163(3):188-94.

57. Santos DK, Brandão YB, Rufino RD, Luna JM, Salgueiro AA, Santos VA, et al. Optimization of cultural conditions for biosurfactant production from Candida lipolytica. 2014;3(3):48-57.

58. Hemlata B, Selvin J, Tukaram KJB, biotechnology a. Optimization of iron chelating biosurfactant production by Stenotrophomonas maltophilia NBS-11. 2015;4(2):135- 43 .

59. Cooper D, Macdonald C, Duff S, Kosaric NJA, microbiology E. Enhanced production of surfactin from Bacillus subtilis by continuous product removal and metal cation additions. 1981;42(3):408 - 12.

60. Arrebola E, Jacobs R, Korsten LJJoAM. Iturin A is the principal inhibitor in the biocontrol activity of Bacillus amyloliquefaciens PPCB004 against postharvest fungal pathogens. 2010;108(2):386-95.

61. Ramyabharathi S, Meena KS, Rajendran L, Karthikeyan G, Jonathan E, Raguchander TJEJoBPC. Biocontrol of wilt-nematode complex infecting gerbera by Bacillus subtilis under protected cultivation. 2018;28(1):1-9.

62. Yánez-Mendizábal V, Zeriouh H, Viñas I, Torres R, Usall J, de Vicente A, et al. Biological control of peach brown rot (Monilinia spp.) by Bacillus subtilis CPA8 is based on production of fengycin-like lipopeptides. 2012;132(4):609-19.

63. Singh P, Tiwary BNJB, Bioprocessing. Isolation and characterization of glycolipid biosurfactant produced by a Pseudomonas otitidis strain isolated from Chirimiri coal mines. India. 2016;3(1):1-16.

64. de Faria AF, Teodoro-Martinez DS, de Oliveira Barbosa GN, Vaz BG, Silva íS, Garcia JS, et al. Production and structural characterization of surfactin (C14/Leu7) produced by Bacillus subtilis isolate LSFM-05 grown on raw glycerol from the biodiesel industry. 2011;46(10):1951-7.

65. Ron EZ. Rosenberg EJEm. Natural roles of biosurfactants: Minireview. 2001;3(4):229-36.

66. Chen J, Wang X-j, Hu J-d. Tao SJHjkxHk. Effect of surfactants on biodegradation of PAHs by white-rot fungi. 2006;27(1):154-9.

67. Oliveira, JGd. Garcia-Cruz CHJBAoB, Technology. Properties of a biosurfactant produced by Bacillus pumilus using vinasse and waste frying oil as alternative carbon sources. 2013;56(1):155-60.

68. Moussa L, Azeiz A, Ahmed Z. Identification and characterization of biosurfactants produced by rodococcus equi and bacillus methlyotrophicus. 2013.

69. Marchut-Mikołajczyk O, Drożdżyński P, Polewczyk A, Smułek W, Antczak TJMCF. Biosurfactant from endophytic Bacillus pumilus 2A: physicochemical characterization, production and optimization and potential for plant growth promotion. 2021;20(1):1-11.

70. 70 .

71. da Silva VL, Lovaglio RB, Tozzi HH, Takaki M, Contiero JJJMBSR. Rhamnolipids: a new application in seeds development. 2015;1:100-6.

72. Parr J, Norman AJBG. Considerations in the use of surfactants in plant systems. A review. 1965;126(2):86-96.

73. Ma F, Cholewa E, Mohamed T, Peterson CA, Gijzen MJAoB. Cracks in the palisade cuticle of soybean seed coats correlate with their permeability to water. 2004;94(2):213-28.

74. Mukherjee S, Das P, Sen RJTiB. Towards commercial production of microbial surfactants. 2006;24(11):509-15.

75. Heydecker W, Coolbear PJSs, technology. Seed treatments for improved performance survey and attempted prognosis. 1977.

76. Schellenberger R, Touchard M, Clément C, Baillieul F, Cordelier S, Crouzet J, et al. Apoplastic invasion patterns triggering plant immunity: plasma membrane sensing at the frontline. 2019;20(11):1602-16.

77. Cawoy H, Mariutto M, Henry G, Fisher C, Vasilyeva N, Thonart P, et al. Plant defense stimulation by natural isolates of Bacillus depends on efficient surfactin production. 2014;27(2):87-100.

78. Begum M, RAI VR, Lokesh SJIp. Effect of plant growth promoting rhizobacteria on seed borne fungal pathogens in okra. 2012.

79. Patten CL, Glick BRJA. microbiology e. Role of Pseudomonas putida indoleacetic acid in development of the host plant root system. 2002;68(8):3795801.

80. Duarah I, Deka M, Saikia N, Boruah HDJB. Phosphate solubilizers enhance NPK fertilizer use efficiency in rice and legume cultivation. 2011;1(4):227-38.

\section{Figures}




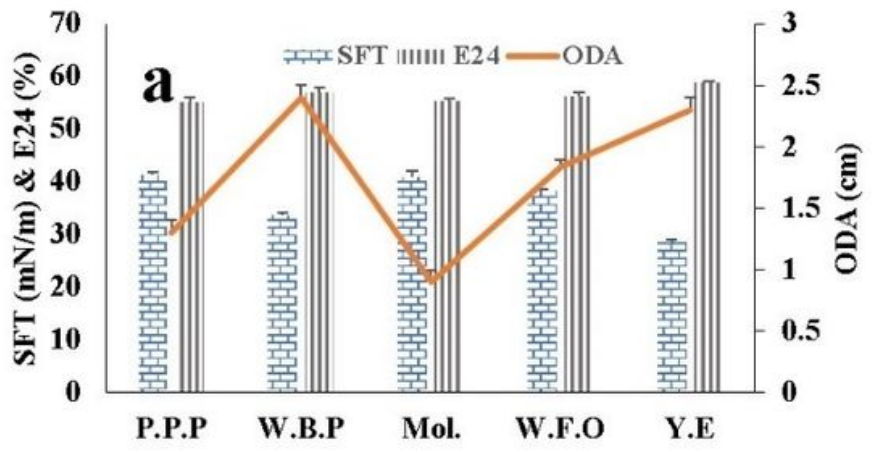

Carbon source $(2 \%, w / v)$

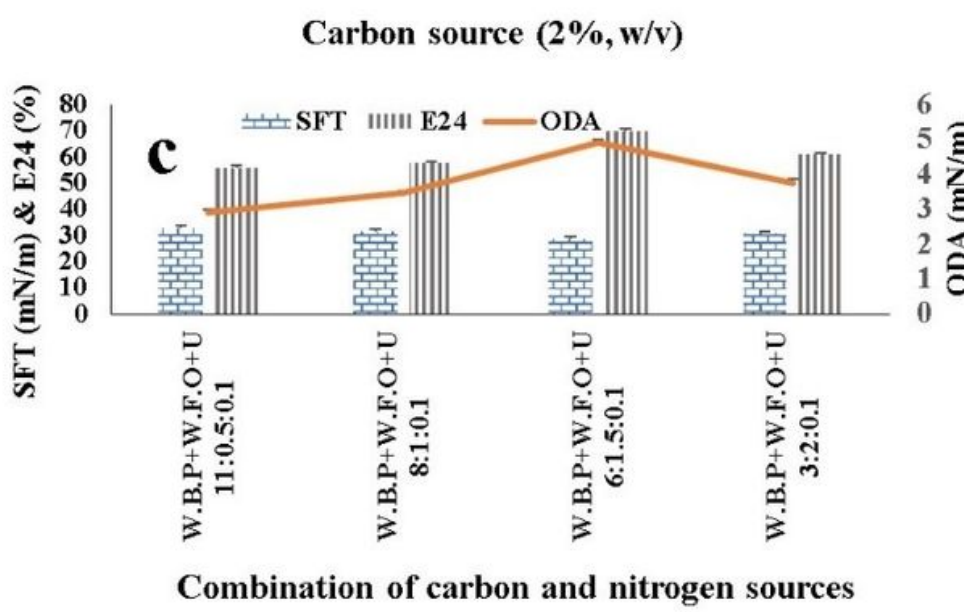

Combination of carbon and nitrogen sources

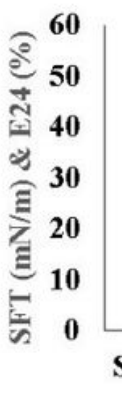

b

SFT ו"ш⿻上E24

-ODA

2.5

2

1.5 출

1

\%

0.5

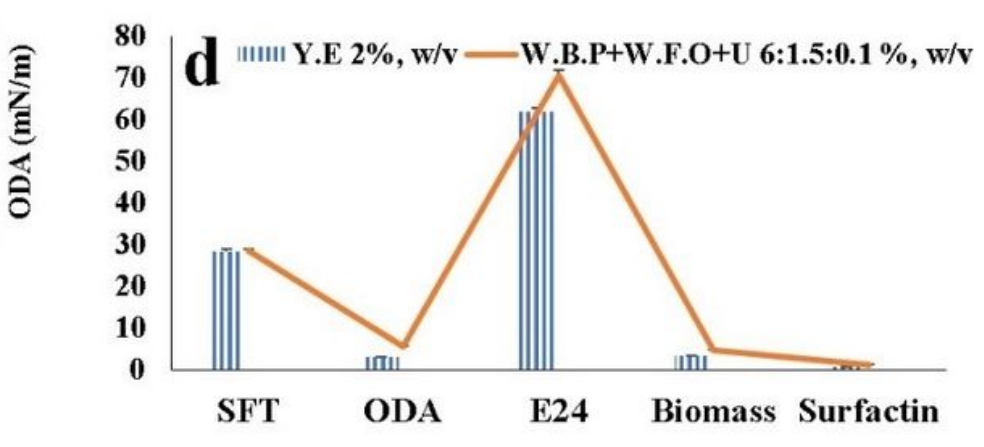

Production analysis under optimized conditions

Figure 1

SFT, E24 and ODA values for biosurfactant production by Bacillus subtilis SNW3 (a) with alternative carbon sources used individually; (b) different nitrogen sources; (c) with combination of carbon and nitrogen energy sources and (d) production analysis of surfactin under optimized conditions with yeast extract as reference, in shake flask fermentation at $30^{\circ} \mathrm{C}$. (Abbreviation: P.P.P Potato peels powder, W.B.P White beans powder, Mol. Molasses, W.F.O Waste frying oil and Y.E Yeast extract). 

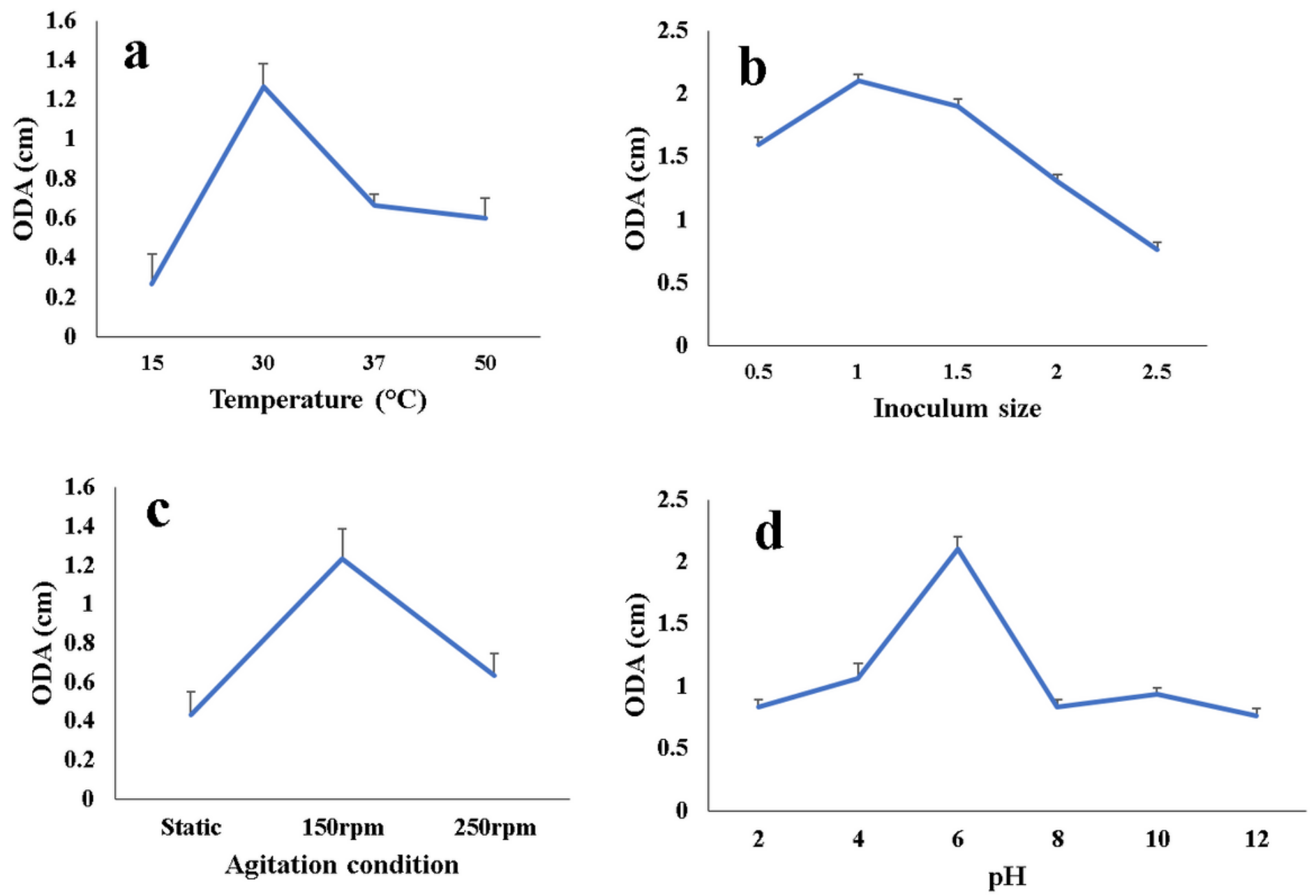

Figure 2

Effect of cultural conditions on ODA of surfactin produced by Bacillus subtilis SNW3, (a) Temperature; (b) inoculum; (c) agitation and (d) pH, error bars represents \pm standard deviation that obtained after mean value of triplicate experiments. 


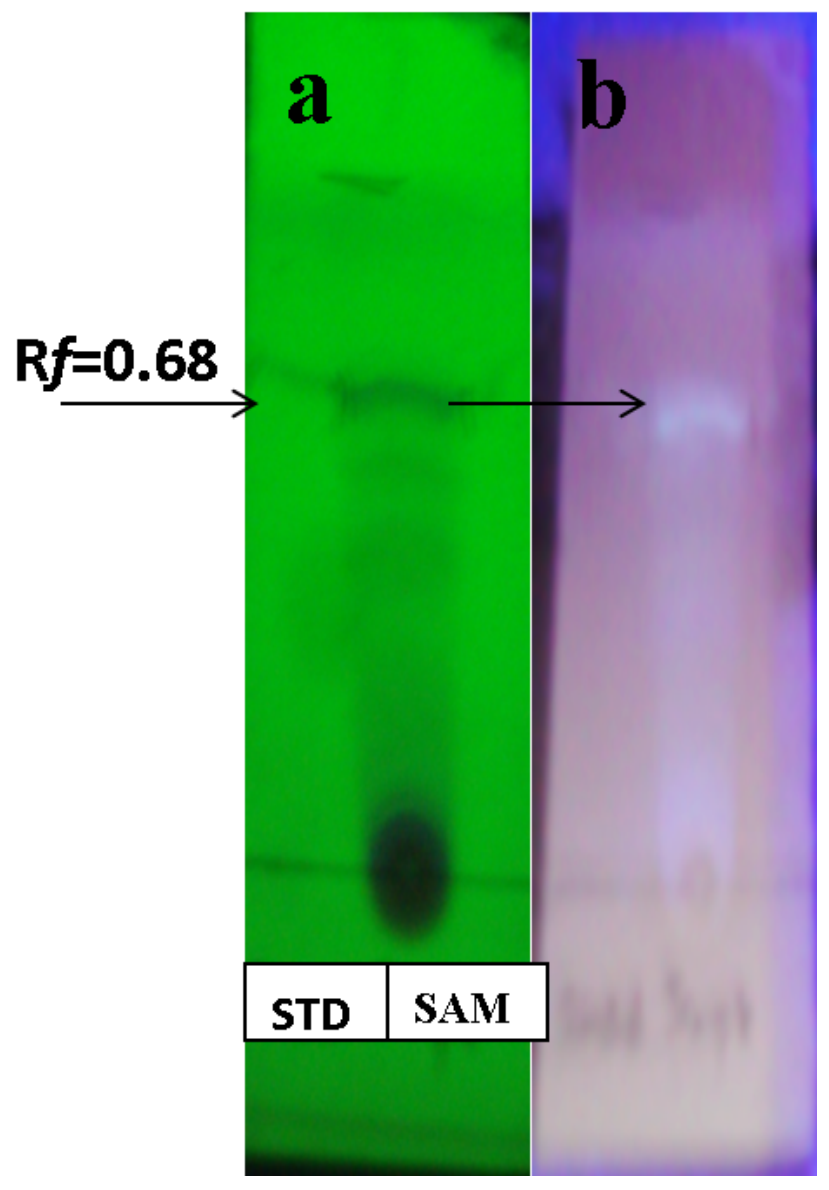

\section{Figure 3}

TLC profile of surfactin produced by Bacillus subtilis SNW3 in sample crude extract opposite to standard surfactin both TLC plates indicate lipopeptide surfactin production under (a) short-waved $254 \mathrm{~nm}$ wavelength and (b) long-waved $365 \mathrm{~nm}$ wavelength; UV ultraviolet light. (Abbreviation: STD Standard, SAM Sample).
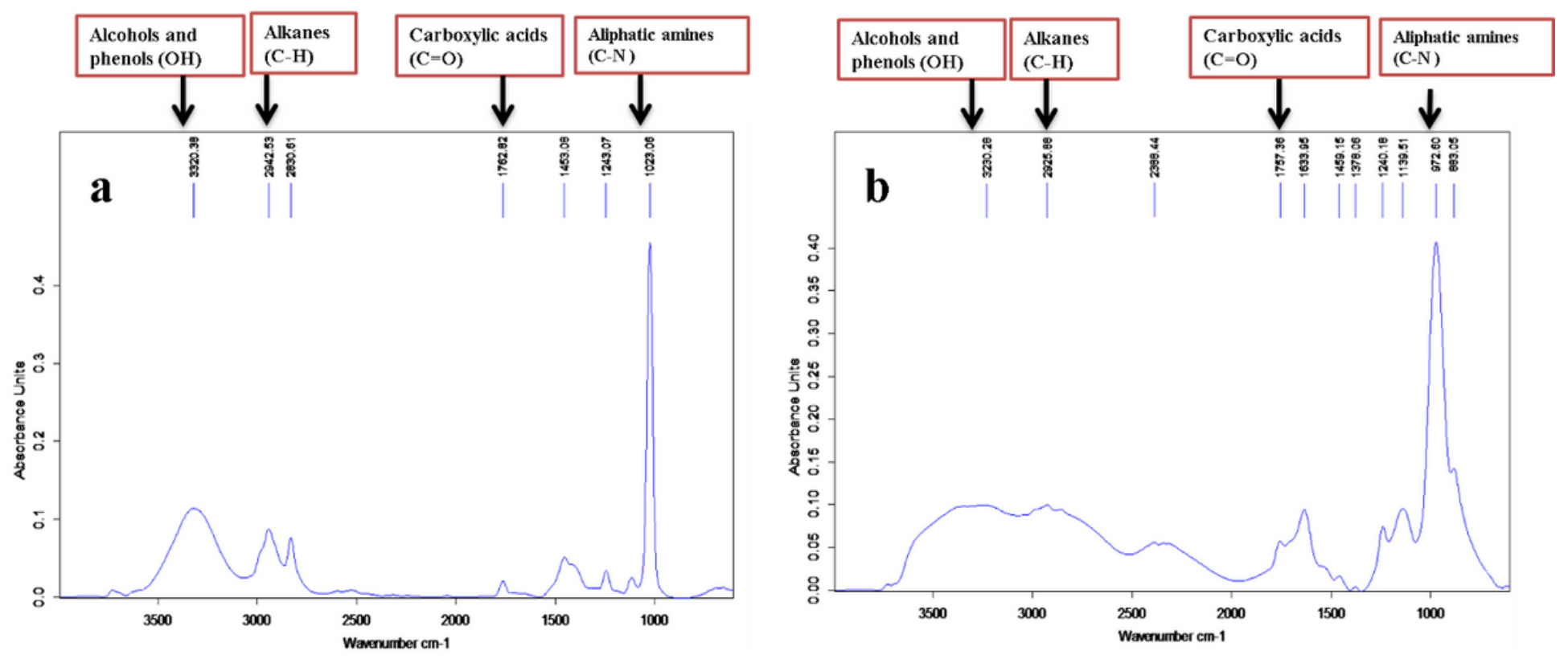

Figure 4

FTIR spectra of (a) standard surfactin and of (b) crude extract of biosurfactant produced by Bacillus subtilis SNW3. 

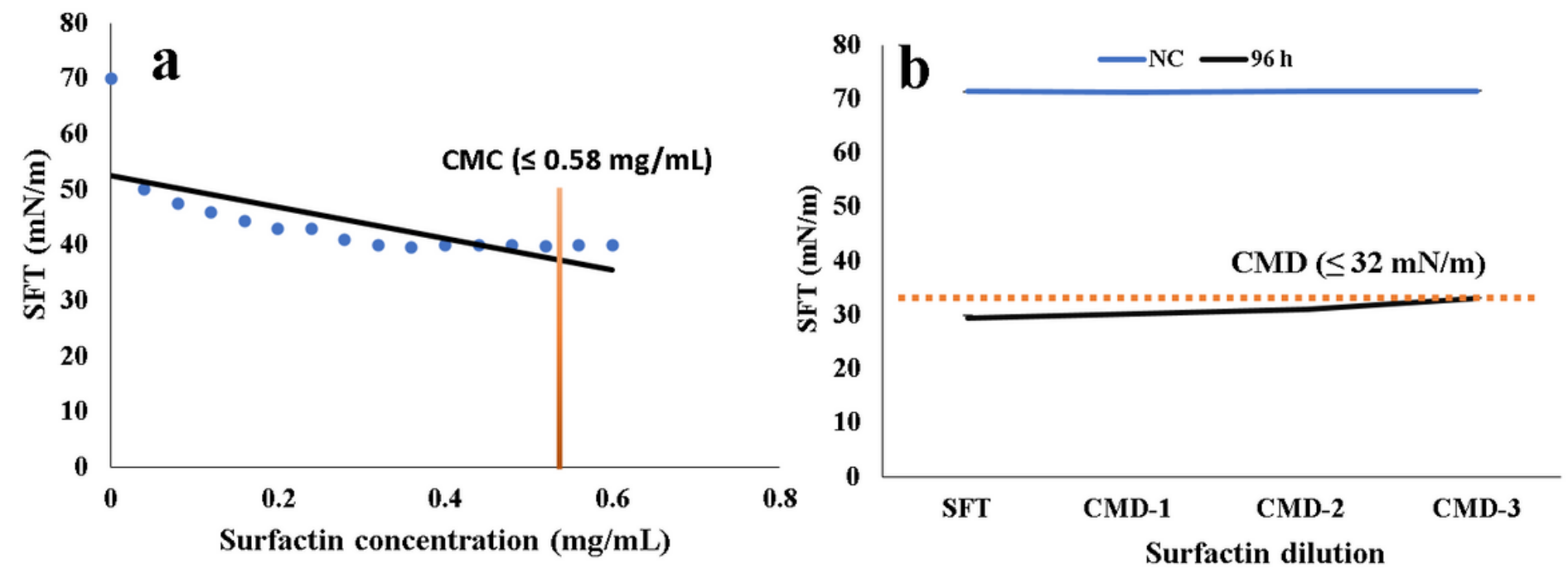

Figure 5

Surfactin analysis by (a) critical micelles concentration (CMC) and (b) critical micelles dilution (CMD); produced by Bacillus subtilis SNW3 in relation to SFT measurement under optimized conditions.

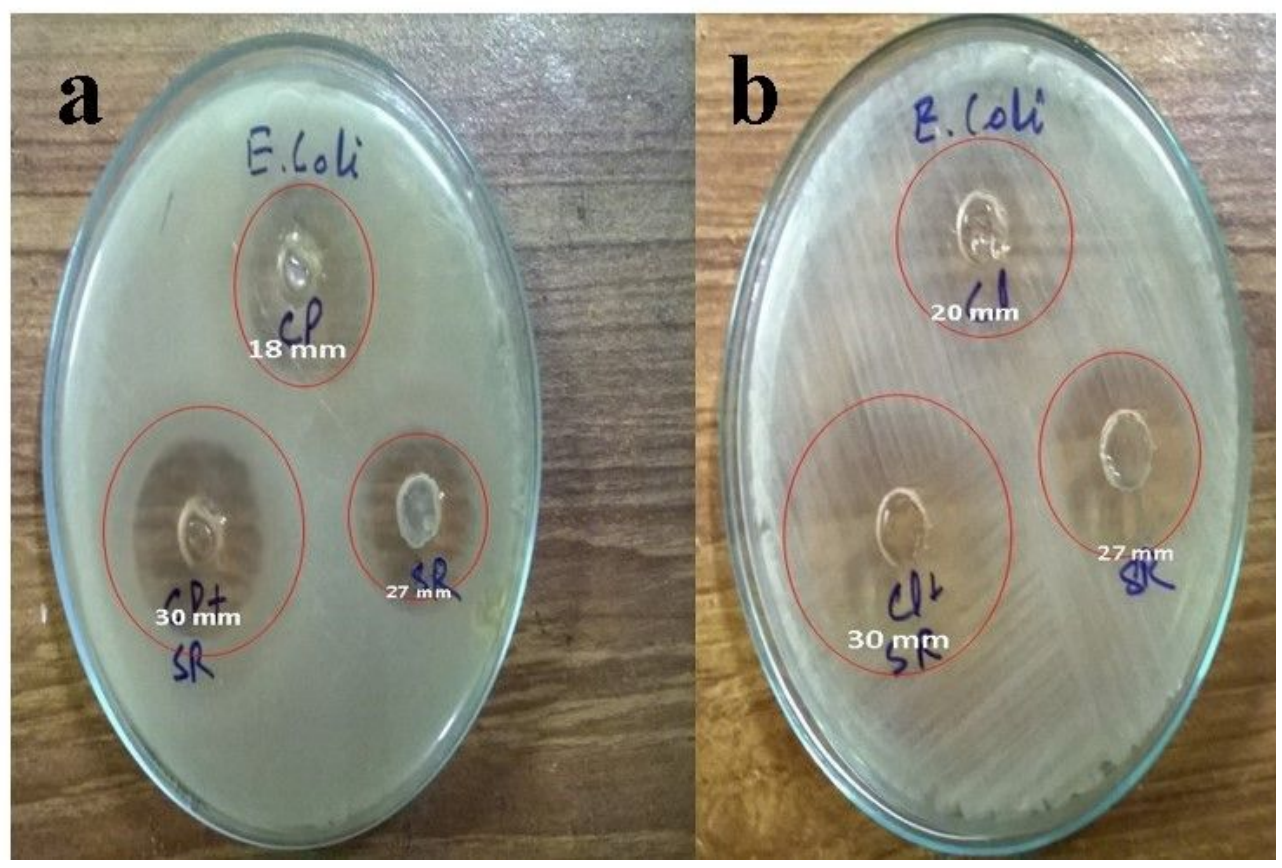

Figure 6

Antibiogram of surfactin produced with antibiotics (a) ciprofloxacin and (b) clarithromycin; tested against Escherichia coli. 


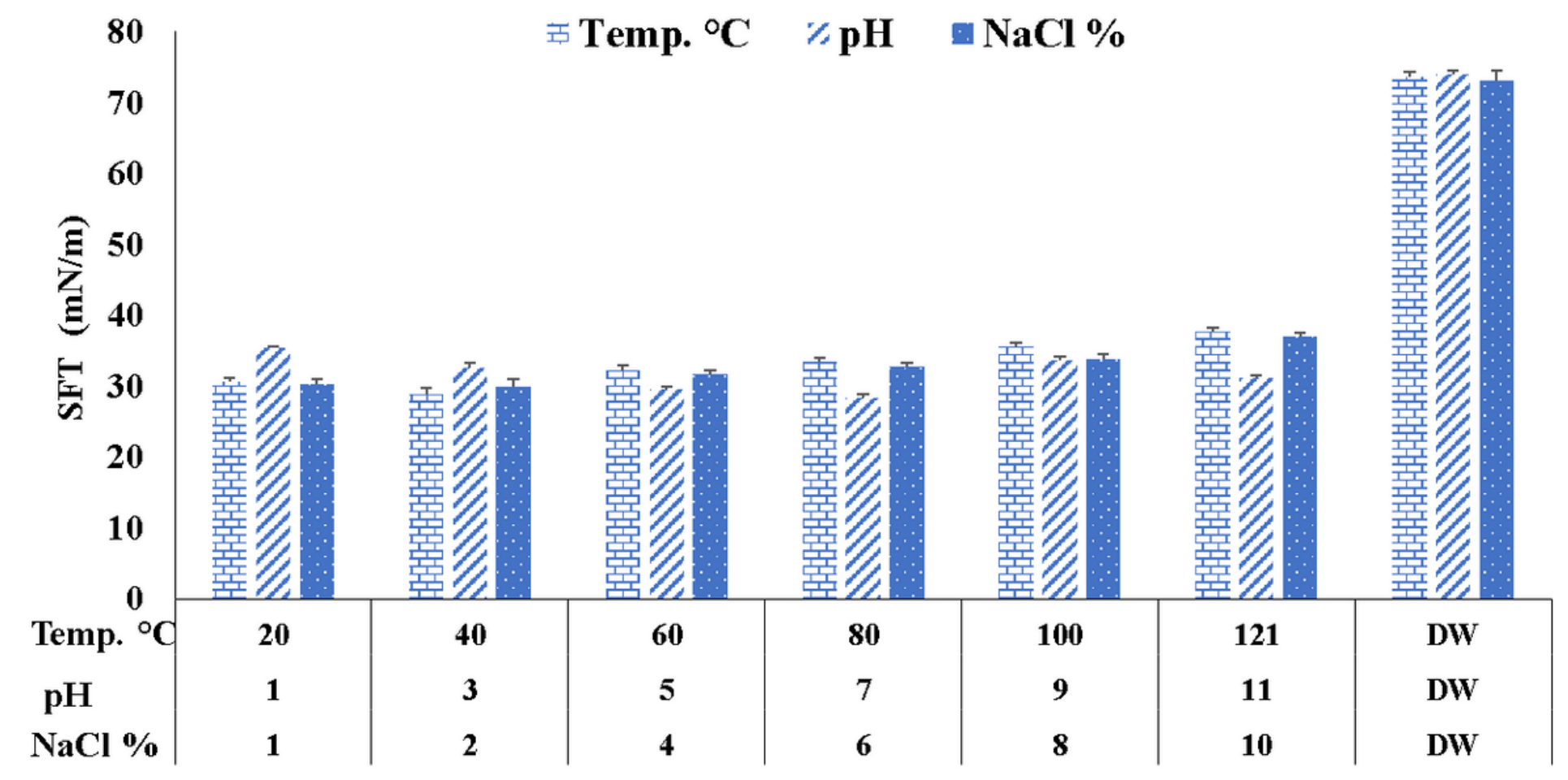

Figure 7

Stability of crude biosurfactant on various environmental factors like temperature ranges $20-121^{\circ} \mathrm{C}, \mathrm{NaCl}$ conc. $1-10 \%(\mathrm{w} / \mathrm{v})$, and $\mathrm{pH}$ ranges $1-11$ (Abbreviation: DW distilled water, Temp Temperature, $\mathrm{NaCl}$ Sodium Chloride).
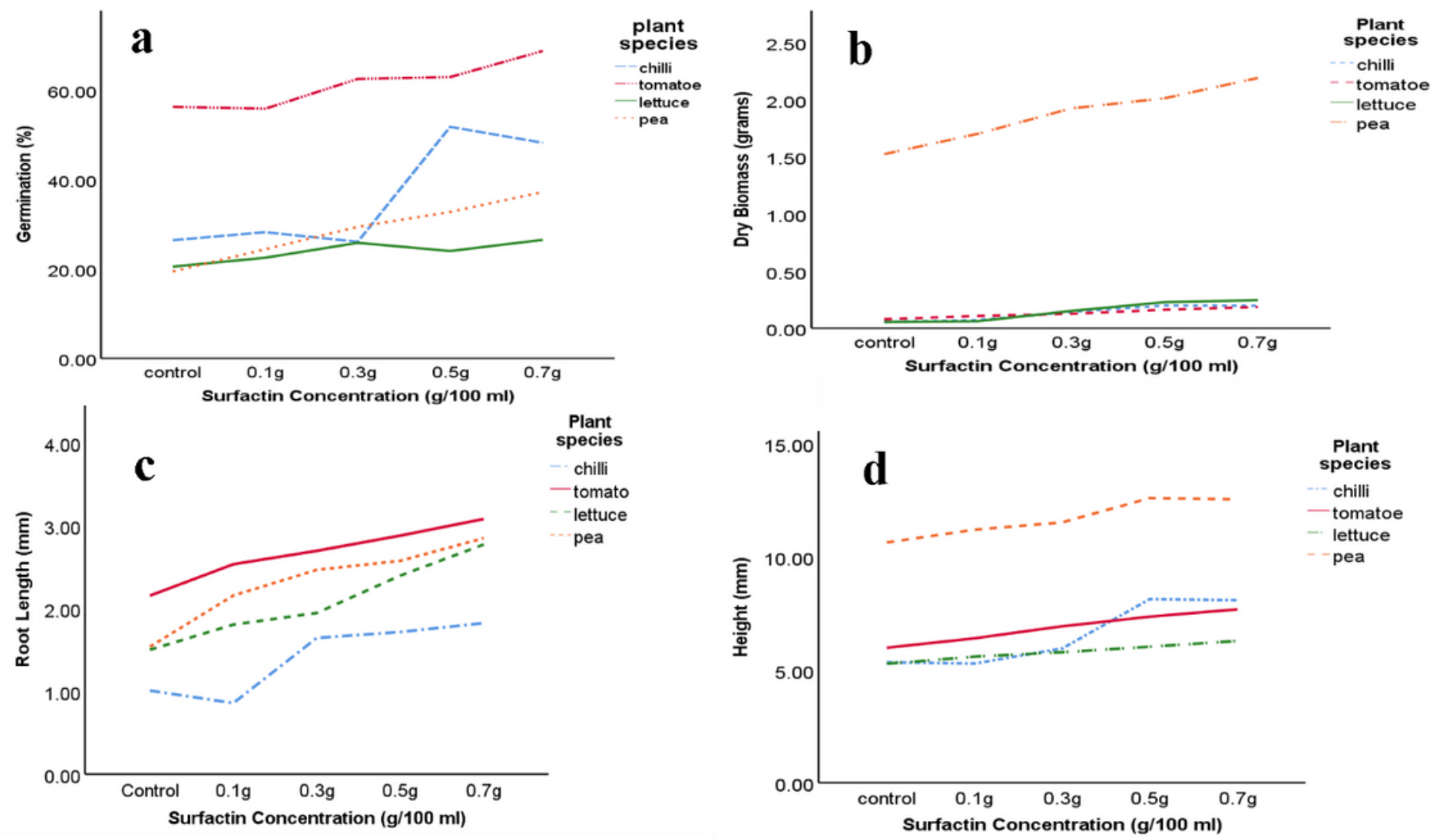

Figure 8

Effect of biosurfactant obtained from Bacillus subtilis SNW3 cultivated on white beans powder and waste frying oil on (a) percent germination of seeds; (b) dry biomass (c) root length and (d) height of plants. 


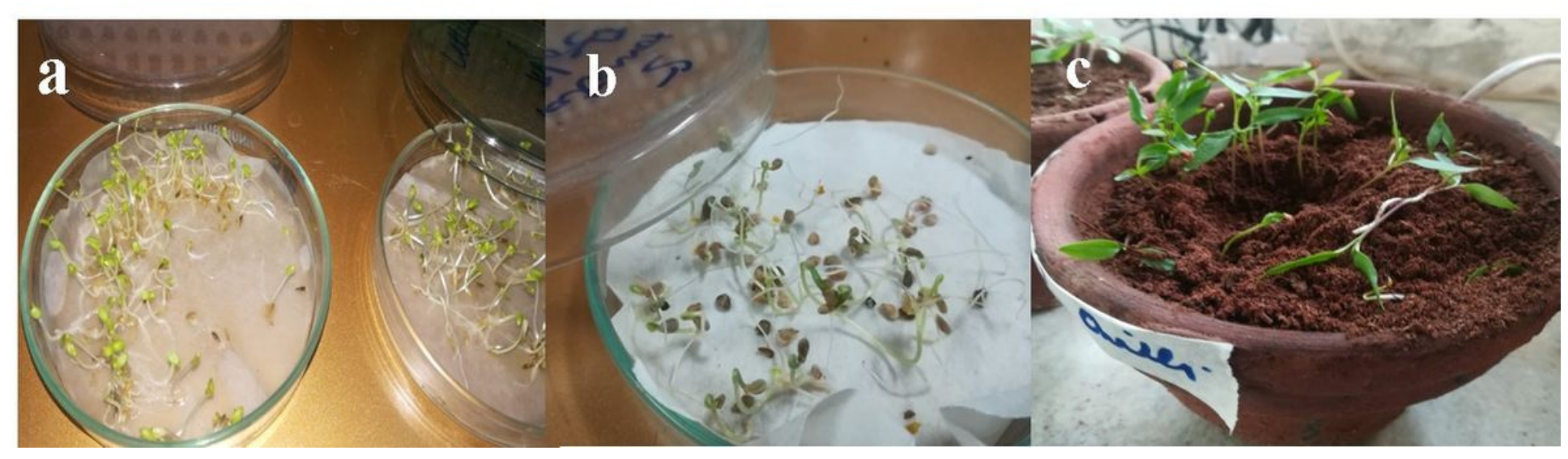

Figure 9

Effect of different concentrations of surfactin on seed germination of (a) lettuce; (b) tomato and (c) chilli plant growth in pot experimental setup. 